\title{
PD-1 immunobiology in glomerulonephritis and renal cell carcinoma
}

\author{
Colleen S. Curran ${ }^{1 *}$ (D) and Jeffrey B. Kopp ${ }^{2}$
}

\begin{abstract}
:
Background: Programmed cell death protein (PD)-1 receptors and ligands on immune cells and kidney parenchymal cells help maintain immunological homeostasis in the kidney. Dysregulated PD-1:PD-L1 binding interactions occur during the pathogenesis of glomerulopathies and renal cell carcinoma (RCC). The regulation of these molecules in the kidney is important to PD-1/PD-L1 immunotherapies that treat RCC and may induce glomerulopathies as an adverse event.

Methods: The expression and function of PD-1 molecules on immune and kidney parenchymal cells were reviewed in the healthy kidney, PD-1 immunotherapy-induced nephrotoxicity, glomerulopathies and RCC.

Results: PD-1 and/or its ligands are expressed on kidney macrophages, dendritic cells, lymphocytes, and renal proximal tubule epithelial cells. Vitamin D3, glutathione and AMP-activated protein kinase (AMPK) regulate hypoxic cell signals involved in the expression and function of PD-1 molecules. These pathways are altered in kidney disease and are linked to the production of vascular endothelial growth factor, erythropoietin, adiponectin, interleukin (IL)18, IL-23, and chemokines that bind CXCR3, CXCR4, and/or CXCR7. These factors are differentially produced in glomerulonephritis and RCC and may be important biomarkers in patients that receive PD-1 therapies and/or develop glomerulonephritis as an adverse event

Conclusion: By comparing the functions of the PD-1 axis in glomerulopathies and RCC, we identified similar chemokines involved in the recruitment of immune cells and distinct mediators in T cell differentiation. The expression and function of PD-1 and PD-1 ligands in diseased tissue and particularly on double-negative T cells and parenchymal kidney cells needs continued exploration. The possible regulation of the PD-1 axis by vitamin D3, glutathione and/or AMPK cell signals may be important to kidney disease and the PD-1 immunotherapeutic response.
\end{abstract}

Keywords: Vitamin D3, Glutathione, 5' AMP-activated protein kinase (AMPK)

\section{Background}

The kidneys perform diverse functions in maintaining human health. These include removing metabolic waste products; contributing to water, electrolyte and acidbase homeostasis; controlling blood pressure via regulation extracellular volume and production of renin and angiotensin; regulating vitamin D3 synthesis and

\footnotetext{
* Correspondence: colleen.curran@nih.gov

${ }^{1}$ Critical Care Medicine Department, Clinical Center, NIH, BG 10 RM 2C135, 10 Center Drive, Bethesda, MD 20814, USA

Full list of author information is available at the end of the article
}

metabolism; and producing erythropoietin which is critical for red blood cell production [1]. Shifts in oxygen consumption or plasma vitamin D3 $\left(1 \alpha-25(\mathrm{OH})_{2} \mathrm{D}_{3}\right)$ levels disrupt various kidney functions $[2,3]$ and contribute to the functions of the programmed cell death protein (PD)-1 receptor and its ligands (PD-L1, PD-L2) $[4,5]$. The expression of these checkpoint molecules on kidney immune cells and epithelial cells [6] is associated with some forms of glomerulonephritis and renal cell carcinoma (RCC) [7, 8]. PD-1 antibodies are being assessed as therapies for renal cell carcinoma (RCC) and

(c) The Author(s). 2021 Open Access This article is licensed under a Creative Commons Attribution 4.0 International License, which permits use, sharing, adaptation, distribution and reproduction in any medium or format, as long as you give appropriate credit to the original author(s) and the source, provide a link to the Creative Commons licence, and indicate if changes were made. The images or other third party material in this article are included in the article's Creative Commons licence, unless indicated otherwise in a credit line to the material. If material is not included in the article's Creative Commons licence and your intended use is not permitted by statutory regulation or exceeds the permitted use, you will need to obtain permission directly from the copyright holder. To view a copy of this licence, visit http://creativecommons.org/licenses/by/4.0/. The Creative Commons Public Domain Dedication waiver (http://creativecommons.org/publicdomain/zero/1.0/) applies to the data made available in this article, unless otherwise stated in a credit line to the data. 
other cancers, and in this context, glomerular and tubulointerstitial disease is a prominent immune-related adverse event [9-11].

To explore the nephrotoxicity of PD-1 immunotherapies, we examined the function and expression of PD-1 molecules in kidney homeostasis and disease. Because nephrotic and nephritic glomerulopathies and tubulointerstitial nephritis occur in response to PD-1 immunotherapy, we reviewed the PD-1 axis on immune and parenchymal cells in these disorders. The proinflammatory responses in glomerular and tubulointerstitial disease were contrasted with the immune tolerance known to occur in RCC through the expression of PD-1 molecules on immune and kidney parenchymal cells. Possible cell signals in regulating the kidney PD-1 axis were examined with a particular focus on the kidney epithelium. The similarities and differences between these diseases may provide insight into the nephrotoxicity of PD-1 immunotherapies.

\section{The PD-1 axis in the healthy kidney}

Resident innate immune cells in the renal interstitium include macrophages [12], dendritic cells (DCs) [13], and mast cells [14]. Intravenous injection of small immune complexes in a murine model showed that macrophages, localized around peritubular capillaries, recognize immune complexes via $\mathrm{Fc}$ receptors (FcRs), such as FcyRIV, and possibly monitor the transendothelial transport of albumin into the kidney interstitium [12]. The expression of PD-1 or its ligands, PD-L1 and PD-L2, on these macrophages in healthy tissue has yet to be fully explored. PD-L1 and PD-L2 have been identified on murine interstitial DCs and on DCs in the kidney-draining lymph, which capture low-molecular weight antigens and peptides [15]. Moreover, PD-L1 ${ }^{+}$ DCs in kidney lymph nodes promote tolerance via PDL1 binding interactions with PD-1 expressed on cytotoxic $\mathrm{T}$ cells in the draining lymph [16]. Lastly, mast cells localize to blood vessels, epithelial tissues and neural connective tissue (i.e. the three layers of connective tissue that surround each nerve) in vivo [14] and express PD-L1 and PD-L2 on murine bone marrowderived mast cells in vitro [17]. PD-1 immunotherapies may therefore alter the function of PD-1 and its ligands on various immune cells in the healthy kidney.

Human primary renal proximal tubular epithelial cell PD-L1 and PD-L2 expression has been shown in-vivo and in vitro. In biopsies of patients with renal allografts, PD-L1 and PD-L2 mRNA are upregulated and surface expression of PD-L1 was present on infiltrating cells and epithelial cells in the tubulointerstitium. Moreover, in vitro PD-L1 blockade of tubular epithelial PD-L1 binding interactions with PD-1 on $\mathrm{CD} 4^{+}$and $\mathrm{CD} 8^{+} \mathrm{T}$ cells reduces alloreactive $\mathrm{T}$ cell proliferation and cytokine production [6], suggesting a protective effect of PD-L1 on the tubular epithelium (Fig. 1). Although PD-L1 is expressed on fibroblasts and endothelial cells in extra-renal tissues, the presence of this checkpoint molecule on these cells in the kidney has not yet been assessed [18]. The expression of major histocompatibility class (MHC)-II molecules on podocytes and mesangial cells $[19,20]$ suggests that checkpoint molecules may be expressed on these cells, as is the case with professional antigen presenting cells (e.g. macrophages, DCs, and B cells) (Fig. 1). Because PD-1 ligands appear to promote tissue homeostasis, continued research into the function of these molecules on kidney parenchymal cells in response to disease and PD-1 immunotherapies appears warranted.

\section{The PD-1 axis in glomerulopathies and tubulopathies}

Glomerulopathies are acute or more often chronic kidney disorders that develop in the glomeruli, although associated tubulointerstitial injury is common [21]. Glomerulopathies include both non-inflammatory (nephrotic) and inflammatory forms (nephritic) and may evolve strictly in the kidney (primary) or in response to systemic disease (secondary) [22]. Both nephrotic and nephritic syndromes have been associated with anti-PD1 therapy (Table 1). The pathophysiology of the glomerulopathies is diverse. Identified factors may include viral infections (e.g., cytomegalovirus, Epstein-Barr virus, hepatitis $C$ virus, herpes simplex virus), autoimmune disorders (e.g., systemic lupus erythematosus (lupus), Goodpasture syndrome, polyarteritis), certain drugs (e.g., antibiotics, diuretics, chemotherapeutics) [21, 34-36], genetic mutations (e.g., (Apolipoprotein L1 (APOLI)), and unknown factors associated with idiopathic disease (e.g., minimal change disease (MCD)). The development of glomerulopathies secondary to PD-1 immunotherapy is an increasingly recognized complexity of unknown etiology. Patients administered proton pump inhibitors, cytotoxic T-lymphocyte-associated protein 4 (CTLA-4) antibodies, or nonsteroidal anti-inflammatory drugs (NSAIDs) may have a greater risk to renal toxicities in response to PD-1 immunotherapy, resulting in fatal toxic events in as little as 2 weeks compared to greater than a month with PD-1 immunotherapy alone [37, 38]. Understanding the functions of PD-1 receptors in the healthy kidney and disease states that provoke tolerogenic or autoimmune responses may be informative to PD-1 nephrotoxicity clinical presentation, treatment, and algorithms for the use of PD-1 immunotherapy after the resolution of this adverse event.

The nephrotic syndromes associated with PD-1 immunotherapy include minimal change disease (MCD) and focal segmental glomerulosclerosis (FSGS). Both MCD and FSGS, as with other causes of nephrotic syndrome, manifest effacement of the glomerular filtration slits. 


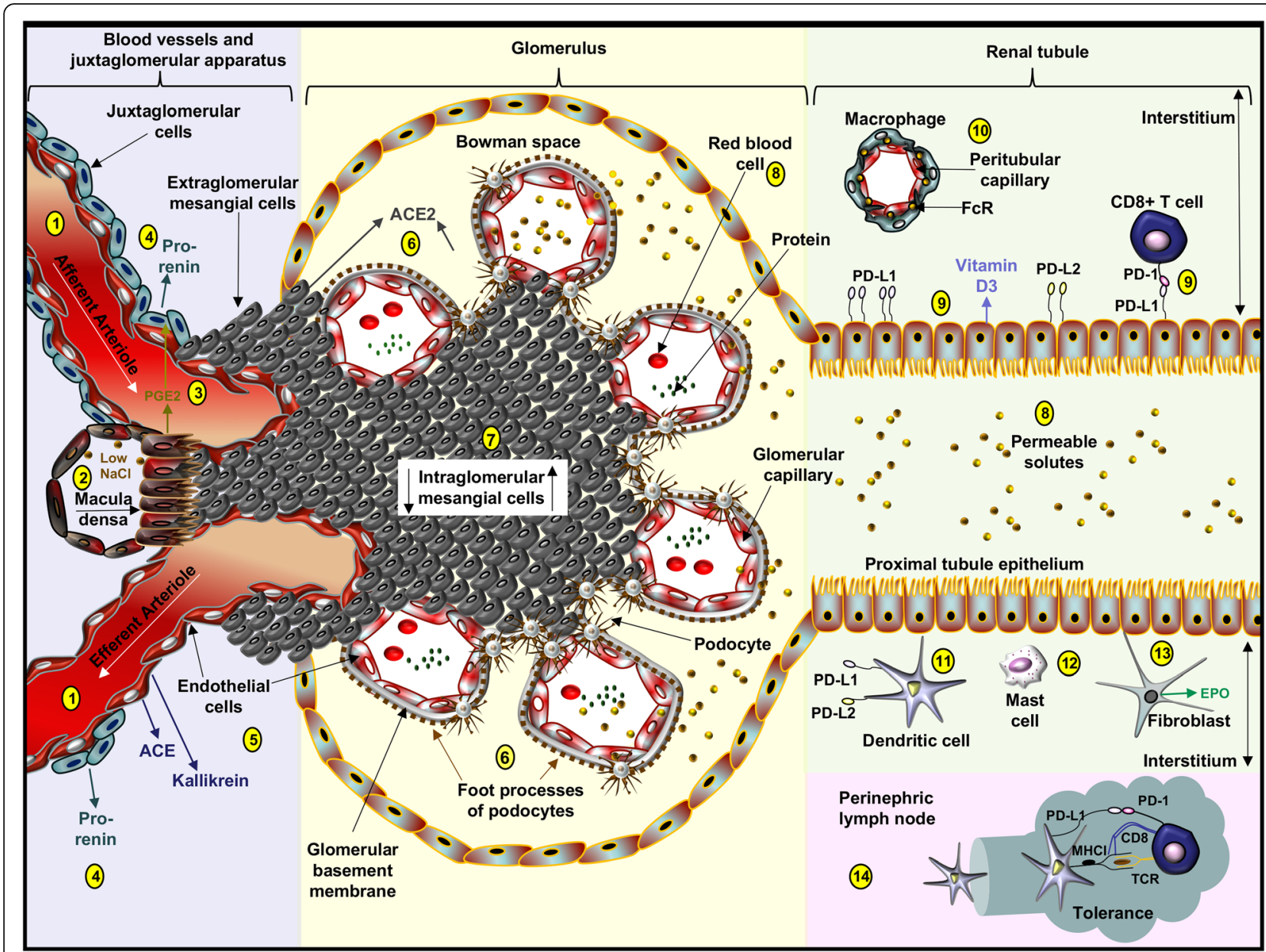

Fig. 1 Healthy juxtaglomerular apparatus, glomerulus, renal tubule, and perinephric lymph node. (1) The glomerular capillary network is supplied by the afferent arteriole and drained by the efferent arteriole. (2) Specialized epithelial cells in the macula densa sense $\mathrm{NaCl}$ concentrations in the distal tubule. (3) Low NaCl concentrations induce cells in the macula densa to secrete prostaglandins (PGE2), which promote afferent arteriolar dilation. (4) PGE2 stimulates the release of pro-renin from juxtaglomerular cells, predominantly located around the afferent arteriole. (5) Pro-renin is cleaved into renin by endothelial cell kallikrein and both renin and angiotensin converting enzyme (ACE) are key enzymes in the reninangiotensin system (RAS). (6) A trilaminar structure in the glomerular capillary wall, composed of the endothelium, glomerular basement membrane, and podocyte foot processes, provides a size-selective and charge-selective filter regulating passage of macromolecules from plasma into the urinary space. Podocytes can produce ACE2. (7) Extraglomerular and intraglomerular cells provide structural support and can produce cytokines and ACE2. (8) Impermeable proteins and blood cells remain in the capillaries but permeable solutes (e.g., $\mathrm{NaCl}$, glucose), small molecules, and many proteins are filtered into Bowman space. (9) Proximal tubule epithelial cells produce vitamin D3 and express PD-L1 and PDL2 where PD-L1 may be integral in CD8 T cell tolerance. (10) Macrophages expressing Fc receptors surround peritubular capillaries and regulate trans-endothelial transport of molecules into the renal interstitium. (11) Interstitial dendritic cells express PD-L1 and PD-L2. (12) Mast cells are infrequently identified in the healthy interstitium. (13) Fibroblasts generate erythropoietin (EPO). (14) Dendritic cells regulate tolerance by presenting innocuous peptides to CD8 ${ }^{+} \mathrm{T}$ cells in the renal lymph in association with PD-L1 ligation to CD8 PD-1

These are passageways between adjacent podocyte foot processes that provide size-selective and charge-selective regulation of the passage of plasma molecules from the glomerular capillary lumen, across the podocyte slitdiaphragm, into Bowman space and on into the proximal tubule lumen. Because the PD-1 immunotherapeutic response is associated with MCD and FSGS, factors involved in the development of these glomerulopathies may be important to the function of PD-1 receptors in the kidney.
MCD is an idiopathic nephrotic syndrome that is responsive to immunosuppressive therapies and rarely if ever progresses to end-stage kidney disease [39]. FSGS also involves podocyte injury and foot process effacement but unlike MCD, often progresses to endstage kidney disease. FSGS is comprised of six syndromes [40].

- Primary FSGS, idiopathic, likely due to a circulating molecule 
Table 1 Glomerulopathy as a complication of anti-PD-1 immunotherapy in 13 cases

\begin{tabular}{|c|c|c|c|c|c|}
\hline Underlying Disease & Age Sex & Disease Treatment & Syndrome & Syndrome Treatment & Result \\
\hline $\begin{array}{l}\text { Metastatic clear cell } \\
\text { renal carcinoma [11] }\end{array}$ & $70 \mathrm{M}$ & $\begin{array}{l}10 \text { months of nivolumab } \\
3 \mathrm{mg} / \mathrm{kg} \text { every } 2 \text { weeks } \\
\text { subsequent to pazopanib } \\
600 \mathrm{mg} \text { daily }\end{array}$ & $\begin{array}{l}\text { Diffuse tubular injury } \\
\text { with vacuoles and } \\
\text { immune complex- } \\
\text { mediated glomerulo } \\
\text { nephritis with cellular } \\
\text { crescents and necrosis }\end{array}$ & $\begin{array}{l}\text { Methylprednisolone } 40 \mathrm{mg} \\
\text { intravenously } 2 x / \text { day that was } \\
\text { increased to } 3 x / \text { day, 1g/day, } \\
\text { and tapered }\end{array}$ & Discharged \\
\hline $\begin{array}{l}\text { Metastatic } \\
\text { squamous cell anal } \\
\text { carcinoma [23] }\end{array}$ & $75 \mathrm{~F}$ & $\begin{array}{l}2 \text { months ( } 5 \text { cycles) of } \\
2.4 \mathrm{mg} / \mathrm{kg} \text { nivolumab } \\
\text { monotherapy subsequent } \\
\text { to colostomy with combined } \\
5 \text {-fluororuacil and mitomycin } \\
\mathrm{C} \text { with radiation }\end{array}$ & $\begin{array}{l}\text { Membranoproliferative } \\
\text { glomerulonephritis }\end{array}$ & Prednisone $40 \mathrm{mg}$ daily & Deceased \\
\hline $\begin{array}{l}\text { Papillary renal cell } \\
\text { carcinoma type } \\
2 \text { [24] }\end{array}$ & $62 M$ & $\begin{array}{l}4 \text { cycles of nivolumab } 3 \mathrm{mg} / \mathrm{kg} \\
\text { every } 2 \text { weeks subsequent to } \\
\text { a cMET inhibitor (INC280), } \\
\text { everolimus pazopanib }\end{array}$ & $\begin{array}{l}\text { Early FSGS, due to } \\
\text { nivolumab or as a } \\
\text { paraneoplastic sign, } \\
\text { an acute tubular } \\
\text { necrosis, or a postrenal } \\
\text { obstruction }\end{array}$ & $\begin{array}{l}\text { IV pulses of } 1000 \mathrm{mg} \\
\text { methyl-prednisolone for } 3 \\
\text { days, followed by prednisone } \\
60 \mathrm{mg} / \text { day and mycophenolate } \\
\text { mofetil } 750 \mathrm{mg} \text { twice daily }\end{array}$ & $\begin{array}{l}\text { Discharged, relapse, } \\
\text { deceased }\end{array}$ \\
\hline $\begin{array}{l}\text { Metastatic lung } \\
\text { adeno-carcinoma [25] }\end{array}$ & $71 \mathrm{~F}$ & $\begin{array}{l}\text { Pembrolizumab following } \\
\text { completion of carboplatin } \\
\text { and pemetrexed treatment }\end{array}$ & $\begin{array}{l}\text { Focally crescentic } \\
\text { pauci-immune } \\
\text { glomerulonephritis }\end{array}$ & $\begin{array}{l}\text { Pulse glucocorticoids followed } \\
\text { by high-dose glucocorticoids }\end{array}$ & $\begin{array}{l}\text { Resolution of proteinuria } \\
\text { and hematuria }\end{array}$ \\
\hline $\begin{array}{l}\text { Squamous cell } \\
\text { carcinoma and the } \\
\text { development of } \\
\text { infectious } \\
\text { enterocolitis [26] }\end{array}$ & $65 \mathrm{M}$ & $\begin{array}{l}\text { Pembrolizumab } 200 \text { mg, } \\
\text { in six infusions, over } 4 \text { months } \\
\text { subsequent to radiation and } \\
\text { cisplatin }\end{array}$ & $\begin{array}{l}\text { Pauci-immune } \\
\text { necrotizing crescentic } \\
\text { glomerulonephritis with } \\
\text { positive peri-nuclear } \\
\text { ANCA and myeloperoxi } \\
\text { dase (MPO) }\end{array}$ & $\begin{array}{l}\text { Methylprednisolone } 1000 \mathrm{mg} / \\
\text { day for } 3 \text { days, followed by } \\
\text { prednisone } 60 \mathrm{mg} / \text { day tapered } \\
\text { to } 50 \mathrm{mg} / \text { day. The patient also } \\
\text { received two doses of } 1000 \\
\text { mg rituximab }\end{array}$ & $\begin{array}{l}\text { Decreased proteinuria } \\
\text { and hematuria }\end{array}$ \\
\hline $\begin{array}{l}\text { Stage IV non-small- } \\
\text { cell lung cancer [27] }\end{array}$ & $67 \mathrm{M}$ & $\begin{array}{l}\text { Nivolumab } 3 \mathrm{mg} / \mathrm{kg} \text { every } 2 \\
\text { weeks subsequent to } \\
\text { bevacizumab combined with } \\
\text { pemetrexed plus cisplatin }\end{array}$ & $\begin{array}{l}\text { Acute tubulointerstitial } \\
\text { nephritis (ATIN) }\end{array}$ & $\begin{array}{l}\text { Lansoprazole was discontinued } \\
\text { and administration of } 500 \mathrm{mg} \\
\text { intravenous } \\
\text { methylprednisolone for } 3 \text { days } \\
\text { followed by } 1 \mathrm{mg} / \mathrm{kg} / \text { day oral }\end{array}$ & $\begin{array}{l}\text { Positive drug induced } \\
\text { lymphocyte stimulating test } \\
\text { (DLST) for lansoprazole and } \\
\text { improved kidney function }\end{array}$ \\
\hline
\end{tabular}

pemetrexed plus cisplatin

followed by maintenance pemetrexed infusion. Lansoprazole $15 \mathrm{mg} /$ day was also prescribed.

\begin{tabular}{|c|c|c|}
\hline $\begin{array}{l}\text { Metastatic anal canal } \\
\text { non-mutated BRAF } \\
\text { melanoma [28] }\end{array}$ & $76 \mathrm{~F}$ & $\begin{array}{l}3 \text { cycles of nivolumab } \\
(3 \mathrm{mg} / \mathrm{kg} \text { ) administered } 8 \\
\text { weeks after ipilimumab (4 } \\
\text { cycles of } 3 \mathrm{mg} / \mathrm{kg} \text { ) } \\
\text { discontinuation }\end{array}$ \\
\hline $\begin{array}{l}\text { Stage IV melanoma } \\
\text { BRAF wild type [29] }\end{array}$ & $68 \mathrm{M}$ & $\begin{array}{l}\text { Single dose of pembrolizumab } \\
(2 \mathrm{mg} / \mathrm{kg}) \text { as first-line therapy }\end{array}$ \\
\hline
\end{tabular}

Metastatic melanoma and prostate cancer in remission [30]

Metastatic acral melanoma [30]

Stage IIA adenocarcinoma of the lung [31]
$64 \mathrm{M} \quad 5$ cycles pembrolizumab

$2 \mathrm{mg} / \mathrm{kg}$ every 3 weeks

$78 \mathrm{~F} \quad 3$ cycles of nivolumab $3 \mathrm{mg} / \mathrm{kg}$ [omeprazole was also prescribed]

4 cycles of biweekly treatments with nivolumab subsequent to radiotherapy and repeated courses of cisplatin, pemetrexed, and bevacizumab [rabeprazole was also prescribed]
Nivolumab-induced acute immune interstitial nephritis

Acute renal failure with nephrotic syndrome due to a minimal change disease related to pembrolizumab

Diffuse active tubulointerstitial nephritis with severe acute tubular cell injury

Diffuse active chronic tubulointerstitial nephritis with acute tubular cell injury

Nivolumab-induced acute tubulointerstitial nephritis with $\mathrm{CD} 163^{+}$ M2 macrophage infiltration
Oral prednisolone at a daily dose of $0.5 \mathrm{mg} / \mathrm{kg}$ (40 mg) and nivolumab eventually discontinued

Oral prednisolone at $100 \mathrm{mg} /$ day and diuretics administered. Pembrolizumab discontinued.

IV methyl-prednisolone 1 $\mathrm{g} /$ day for three days followed by oral prednisone $60 \mathrm{mg} /$ day and immunotherapy discontinued

IV methyl-prednisolone $1 \mathrm{~g} /$ day for 3 days followed by oral prednisone $60 \mathrm{mg}$ daily and immunotherapy discontinued

Prednisolone (55 mg, daily) treatment was initiated. Nivolumab and rabeprazole were discontinued
Improved kidney function

Renal function restored Ipilimumab (3 mg/kg) and nivolumab (1 mg/kg) resulted in a confirmed a deep partial response after 3 doses

With improved renal function patient resumed treatment with ipilimumab instead of pembrolizumab

With improved renal function patient resumed treatment with three cycles of temozolomide

Renal function improved 
Table 1 Glomerulopathy as a complication of anti-PD-1 immunotherapy in 13 cases (Continued)

\begin{tabular}{|c|c|c|c|c|c|}
\hline Underlying Disease & Age Sex & Disease Treatment & Syndrome & Syndrome Treatment & Result \\
\hline $\begin{array}{l}\text { Recurrent gastric } \\
\text { cancer and liver } \\
\text { metastases } \\
{[32]}\end{array}$ & $68 \mathrm{~F}$ & $\begin{array}{l}30 \text { cycles of nivolumab } \\
\text { subsequent to } \\
\text { S-1 plus cisplatin (first-line), } \\
\text { paclitaxel monotherapy } \\
\text { (second-line) and irinotecan } \\
\text { monotherapy (third-line) }\end{array}$ & $\begin{array}{l}\text { Acute granulomatous } \\
\text { tubulointerstitial } \\
\text { nephritis associated } \\
\text { with PD-L1+ lesions } \\
\text { and aggregated } \\
\mathrm{CD}^{+} \mathrm{T} \text { cells }\end{array}$ & $\begin{array}{l}\text { Nivolumab was discontinued, } \\
\text { and the patient was treated } \\
\text { with methylprednisolone } 1.0 \\
\mathrm{mg} / \mathrm{kg}(40 \mathrm{mg} \text { ) daily }\end{array}$ & $\begin{array}{l}\text { Nivolumab was reinstated } \\
\text { up to a total of } 41 \text { cycles } \\
\text { without kidney dysfunction } \\
\text { but the cancer was not } \\
\text { responsive }\end{array}$ \\
\hline $\begin{array}{l}\text { Hodgkin } \\
\text { lymphoma [33] }\end{array}$ & $40 \mathrm{M}$ & $\begin{array}{l}3 \text { doses of camrelizumab } \\
\text { ( } 200 \text { mg every } 2 \text { weeks) } \\
\text { subsequent to classic } \\
\text { chemotherapy }\end{array}$ & $\begin{array}{l}\text { Minimal change } \\
\text { disease }\end{array}$ & $\begin{array}{l}\text { Camrelizumab was } \\
\text { discontinued and patient } \\
\text { was treated with prednisone } \\
(1 \mathrm{mg} / \mathrm{kg} / \text { day })\end{array}$ & Renal function improved \\
\hline
\end{tabular}

Shown are the details of 13 cases which administration of anti-PD-1 antibody was followed by the appearance of glomerulopathy, either nephrotic syndrome or glomerulonephritis. Ipilimumab: monoclonal antibody targeting cytotoxic T-lymphocyte-associated protein 4 (CTLA-4); pembrolizumab, nivolumab: monoclonal antibody targeting PD-1; S-1: oral dihydropyrimidine dehydrogenase inhibitory fluoropyrimidine based on a biochemical modulation of 5-fluorouracil (5-FU)

- Post-adaptive FSGS, due to a mismatch between glomerular load and glomerular capacity

- APOL1 FSGS, due to susceptibility variants in the gene encoding apolipoprotein-L1, seen only in individuals with sub-Saharan ancestry

- High-penetrance genetic FSGS, associated with mutations in $>50$ nuclear and mitochondrial genes

- Virus-associated FSGS, associated with HIV-1, probably with cytomegalovirus and possibly with parvovirus B-19 and Epstein-Barr virus

- Medication-associated FSGS, due to androgens, bisphosphonates, interferon, lithium, chronic use of nephrotoxic drugs, and others

The functions of PD-1 molecules in HIV-1 [41], cytomegalovirus [42], and Epstein-Barr virus [43] have been reviewed elsewhere. PD-1 immunotherapies may therefore induce nephrotic syndromes by altering the activity of underlying identified genes or pathogens.

The nephritic syndromes most often occur in response to the generation of autoantibodies or to a dysregulated complement system. Autoantibodies against viral antigens or host tissue antigens can form circulating immune complexes, which can become passively trapped in the glomerular mesangium or subendothelial space within the glomerular capillary. Alternatively, autoantibodies or complement can directly bind components in the glomeruli [44]. Antibodies that bind complement factors can also alter complement activity. This may include autoantibodies directed against the complement C3 $(\mathrm{C} 3 \mathrm{NeF})$ or $\mathrm{C} 4(\mathrm{C} 4 \mathrm{NeF})$ convertases. These nephritic autoantibodies are present in some forms of membranoproliferative glomerulonephritis (MPGN) [45]. The paracrine activity between complement factors and PD-1 molecules are reviewed elsewhere [46].

MPGN is a histopathologic pattern characterized by increased glomerular cellularity, capillary wall thickening and mesangial expansion. Patients with MPGN may present clinically with nephrotic syndrome or nephritic syndrome [47, 48]. Three different forms of MPGN are recognized. The first is immune complex-associated MPGN (IC-MPGN), which manifests in response to significant glomerular immunoglobulin deposition and activation of the complement classical pathway, leading to the formation of the complement membrane attack complex (MAC) on the surface of targeted cells [47, 48]. IC-MPGN is seen in lupus nephritis, immunoglobulin (Ig)-A nephropathy, infection-related glomerulonephritis and fibrillary glomerulonephritis with polyclonal immunoglobulin deposits [48]. The contribution of altered PD-1 activity in these diseases is discussed elsewhere $[43,49]$. The additional forms are complement-mediated and identified as $\mathrm{C} 3$ glomerulopathy (C3G). The C3G category is divided into dense deposits disease (DDD) and C3 glomerulonephritis (C3GN). DDD involves osmiophilic electron-dense intramembranous deposits whereas $\mathrm{C} 3 \mathrm{GN}$ includes nephritic factors and $\mathrm{C} 3$ deposits predominantly in the glomeruli, without intramembranous deposits $[47,48]$. Crescentic glomerulonephritis can be identified in IC-MPGN and C3GN [50].

Pauci-immune glomerulonephritis (PIGN) is the most common cause of crescentic glomerulonephritis. Approximately $95 \%$ of PIGN cases exhibit antineutrophil cytoplasmic antibodies (ANCA) specific to myeloperoxidase (MPO-ANCA) or proteinase 3 (PR3-ANCA). Autoantibody binding to neutrophils induce neutrophil integrin expression and adherence to endothelial cells, which promotes transmigration across the endothelium [51]. These activated neutrophils release neutrophil extracellular traps (NETs) and granules that damage the endothelium. Ruptures in the glomerular basement membrane release plasma proteins and coagulation factors into Bowman space that promote parietal epithelial cell hyperplasia and form crescentic glomerulonephritis [50].

Tubulointerstitial inflammation and damage are common in progressive glomerular disorders and are the defining features in interstitial kidney disease [34, 35]. In a multicenter retrospective analysis, patients receiving PD1/PD-L1 immunotherapy and a proton pump inhibitor 
or a CTLA-4 inhibitor developed tubulointerstitial nephritis in $93 \%$ of biopsied patients [37]. Renal biopsy is required for the diagnosis of anti-PD-1 immunotherapyinduced glomerulopathies and tubulopathies. In the USA, renal biopsy typically includes analysis of the tissue by light microscopy, electron microscopy and characterization of antibody deposition (IgG, IgM and IgA) and complement deposition. Immune cell infiltrates of myeloid lineage (monocytes, dendritic cells, neutrophils) and lymphoid lineage ( $\mathrm{T}$ cells, $\mathrm{B}$ cells, plasma cells) may be identified by immunohistochemical staining, although this is typically a research procedure and not part of most clinical renal biopsy analyses [34, 35]. In a study assessing kidney biopsies obtained from anti-PD-1 immunotherapy patients that developed acute kidney injury, biopsy samples manifesting acute interstitial nephritis also showed increases in PD-L1 staining on tubular epithelial cell membranes compared to control biopsy samples with acute tubular necrosis [9]. Additional pathologies associated with glomerulonephritis as an adverse event of anti-PD-1 immunotherapeutic treatment are described in Table 1.

\section{Macrophages in glomerulonephritis}

Monocytes and macrophages are recruited by multiple factors, most notably by chemokine (C-C motif) ligand-2 (CCL2). This chemokine, also known as monocyte chemoattractant protein-1 (MCP-1), is produced in the kidney by mesangial cells and proximal tubule epithelial cells in response to cytokines (e.g., tumor necrosis factor (TNF), interferon- $\gamma$, IL-1 $\beta$ ) and by pathogen-associated molecular patterns (PAMPs) (e.g. lipopolysaccharide) [52, 53]. Mesangial cells and proximal tubule epithelial cells also produce macrophage colony-stimulating factor (M-CSF), which promotes differentiation of monocytes into macrophages [54] (Fig. 2). The pathogenic role of macrophages in glomerulonephritis has been established in animal models that demonstrate improved kidney function after macrophage depletion [55, 56]. In addition, in a glomerulonephritis murine model, glomerular macrophages expressed high levels of PD-L1 and proteinuria was suppressed either by blocking macrophage recruitment with anti-CD11b therapy or alternatively by antagonizing PD-L1 function with anti-PD-L1 therapy [55], suggesting a functional role of PD-L1 activated macrophages in the disease.

\section{Fibrotic lesions and germinal centers in glomerulonephritis}

In the setting of glomerulonephritis, interferon- $\gamma$ producing $\mathrm{CD} 56^{\text {bright }} \mathrm{NKp} 46^{+} \mathrm{CD} 117^{+}$natural killer (NK) cells are recruited in human fibrotic kidney tissue [57]. Interferon- $\gamma$ produced by these cells induces production of the macrophage chemokine, CCL2, by mesangial cell and proximal tubule epithelial cells [53]. In response to tubular injury, macrophages, DCs, and mast cells are recruited and may contribute to fibrosis through production of transforming growth factor- $\beta$ - or galectin3 -induced fibroblast proliferation and protease remodeling of the extracellular matrix (e.g., matrix metalloprotease- 9 , chymase, and tryptase) $[14,58]$.

The resulting tubulointerstitial fibrotic lesions manifest the following features: dysregulated production and organization of extracellular matrix proteins and reduced production of erythropoietin by fibroblasts [59], lymphatic growth [60] and the development of germinal center structures containing follicular dendritic cell (FDC) networks, B and $\mathrm{T}$ cell aggregates and plasma cells [61] (Fig. 2). In murine splenic germinal center formation, PD-1 and the ligands regulate the activity of $B$ and $T$ cells $[62,63]$, suggesting that germinal centers formed in the kidney may also require PD-1 cell signals, although this has not been shown. Erythropoietin therapy in the murine nephritis $\mathrm{MRL} / \mathrm{lpr}$ strain promotes the formation of immunosuppressive $\mathrm{T}$ cell subsets [64]. Interstitial fibroblasts produce erythropoietin and with further investigation, could regulate PD-1 cell signals associated with $\mathrm{T}$ cell suppression. The PD-1 axis is therefore an attractive therapeutic target to suppress both germinal center activity and fibrosis in progressive kidney disease.

\section{Neutrophils in glomerulonephritis}

Although peripheral numbers of PD-L1-expressing neutrophils are elevated in lupus patients [65], this marker is generally absent from neutrophils in the human kidney and is absent from intraglomerular neutrophils in the NZM2328 murine model of lupus nephritis [55]. Neutrophils, which contribute to the pathology of inflammation in the glomeruli and the interstitium in lupus, are mainly recruited into the kidney by IL- 8 released from cells activated by cytokines (e.g., TNF or IL$1 \alpha)$, including podocytes, mesangial cells and proximal tubular epithelial cells $[66,67]$. In lupus nephritis, enhanced production of IL-8 occurs in response to the cytokine IL-17 [68], which is produced predominantly by double-negative $\mathrm{TCR} \alpha \beta^{+} \mathrm{CD}^{+} \mathrm{CD} 4^{-} \mathrm{CD} 8^{-} \mathrm{T}$ cells [69]. The functions of double-negative $\mathrm{T}$ cells (i.e. those lacking CD4 and CD8), which can also express PD-1 [70], may therefore include the recruitment of neutrophils.

\section{Lymphocytes in glomerulonephritis}

Double-negative $\mathrm{T}$ cells [69], IL-17 producing $\mathrm{CD}^{+} \mathrm{T}$ cells (Th17) [71], and interferon- $\gamma$ producing $\mathrm{CD}^{+} \mathrm{T}$ cells (Th1) [72] are recruited to the glomeruli and the interstitium. The chemokine receptor, CXCR3, is expressed on $\mathrm{T}$ cells and contributes to $\mathrm{T}$ cell recruitment in murine glomerulonephritis [73, 74]. In renal biopsy tissue from lupus nephritis patients, $\mathrm{CXCR}^{+} \mathrm{T}$ cells are present in the kidney and co-localize with cells which produce the CXCR3 ligand, CXCL10 [75]. Serum levels of CXCL10 in lupus patients are positively 


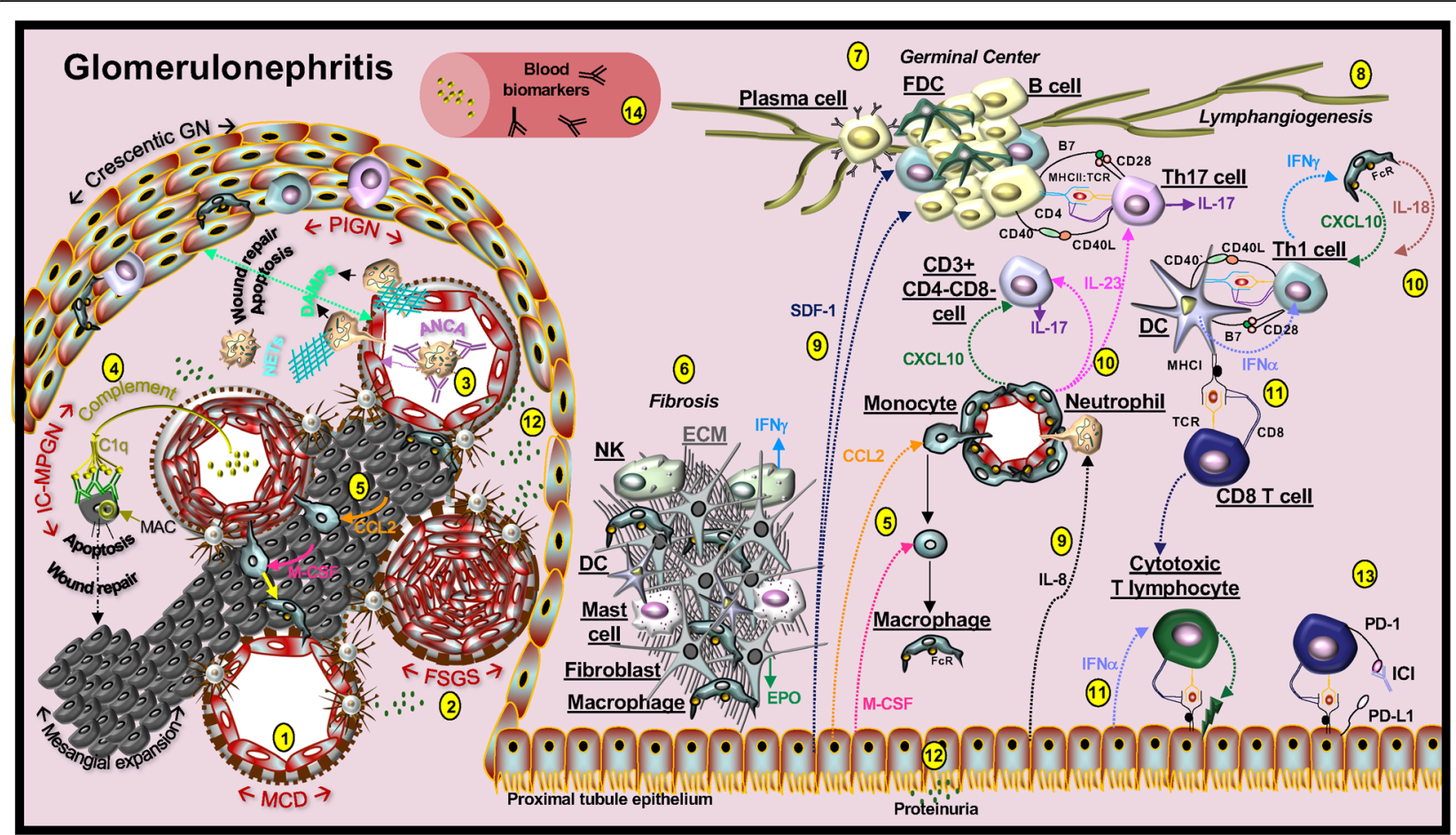

Fig. 2 The microenvironment in glomerulonephritis. Types of glomerulopathy that may occur during PD-1 immunotherapy include minimal change disease (MCD), focal segmental glomerulosclerosis (FSGS), pauci-immune glomerulonephritis (PIGN), and membranoproliferative glomerulonephritis (MPGN). (1) In MCD, injured podocytes undergo foot process effacement whereby they lose filtration slits and cell-cell junctions, leading to loss of the size-selective and charge-selective filtration barrier. (2) FSGS also involves podocyte injury that progresses to the obliteration of the capillary lumens. (3) Antineutrophil cytoplasmic antibody (ANCA)-associated glomerulonephritis is a primary form of PIGN. Autoantibodies activate neutrophils to adhere to the endothelium, and these cells migrate into tissue and release damage-associated molecular pattern molecules (DAMPs). Activated neutrophils also release neutrophil extracellular traps (NETs) and granules that damage the endothelium and rupture the glomerular basement membrane. The subsequent release of plasma proteins and coagulation factors into Bowman space promote parietal epithelial cell hyperplasia and result in crescentic glomerulonephritis. (4) Immune complex MPGN (IC-MPGN) is characterized by capillary wall thickening, mesangial expansion, and may involve the formation of crescentic glomerulonephritis. Complement C1q binds autoantibodies which bind to mesangial cells and promote the deposition of the membrane attack complex (MAC). This pore-forming complex can damage cells in a lethal or sublethal manner. The subsequent wound repair response encourages cell proliferation. (5) Inflammatory cytokines induce mesangial cell and proximal tubule epithelial cell production of CCL2, which recruits macrophages and monocytes, and M-CSF, which promotes monocyte to macrophage differentiation. (6) Tubulointerstitial fibrotic lesions are characterized by excessive accumulation of extracellular matrix (ECM) molecules and the recruitment of natural killer (NK) cells, macrophages, dendritic cells (DCs), and mast cells. (7) Germinal center structures may form and contain follicular dendritic cell (FDC) networks, B and T cell aggregates and plasma cells can form. (8) Lymphangiogenesis can occur in glomerulonephritis. (9) Epithelial cells produce stromal cell-derived factor 1 (SDF1) to recruit B and T cells and IL-8 for neutrophil chemotaxis. (10) Myeloid cells produce IL-23 and IL-18, which induces the formation of Th17 and Th1 cells. These cells are are recruited to the interstitium and glomerulus, in part, by myeloid CXCXL10. NK cells and Th1 cells produce interferon (IFN)- $\gamma$. Most IL-17 producing cells in glomerulonephritis are $\mathrm{CD} 3^{+} \mathrm{CD} 4{ }^{-} \mathrm{CD} 8^{-}$double negative. CD4+ IL-17 producing cells are also present. (11) IFN-a is primarily secreted by activated plasmacytoid DCs and by human proximal tubular epithelial cells in the interstitium. Cytotoxic T lymphocytes (CTL) are generated that destroy target cells. (12) Proteinuria is an identified marker of nephritis. (13) Immune checkpoint inhibitor (ICI) therapies may block homeostatic interactions that normally suppress inflammation. (14) Glomerulonephritis blood markers can include elevated levels of autoantibodies and altered complement turnover

correlated with anti-DNA antibody levels [76]. Moreover, in a murine tumor model, anti-PD-1 therapy increases expression of CXCL10 at the tumor site [77]. Therapeutically targeting CXCL10 or CXCR3 may therefore reduce the inflammatory response in glomerulonephritis $[75,76]$ and may possibly affect the PD-1 axis. In addition, murine splenic self-reactive double-negative $\mathrm{T}$ cells can express PD-1 and this subset produces higher levels of IL-17 compared to their PD-1 ${ }^{-1-}$ counterparts
[70]. Double-negative $\mathrm{T}$ cells and FOX3P ${ }^{+} \mathrm{T}$ regulatory cells (Tregs) are present in lupus renal biopsies [78]. The evaluation of PD-1 on these subsets in human kidney biopsy, as a biomarker or therapeutic target, remains to be explored.

\section{Cytokines in glomerulonephritis}

In glomerulonephritis, increased production of the cytokines IL-23 and IL-18, generated by antigen presenting 
cells, induces the expansion of IL-17-producing cells and interferon- $\gamma$-producing cells, respectively $[79,80]$. In $\mathrm{CD} 4{ }^{+}$Th17 and $\mathrm{CD} 4{ }^{+}$Th1 cells, PD- 1 expression is repressed [43]. Blocking IL-23 or IL-18 cell signals may therefore offer an approach to reduce inflammation and increase PD-1 expression in glomerulonephritis, which could be tested in relevant animal models.

\section{Treatment of glomerulonephritis}

Ideally, treatment of glomerulonephritis involves the direct targeting of the mechanisms underlying the disease process. Idiopathic glomerulonephritis and syndromes involving autoantibodies or complement commonly require immunosuppressive therapies and when these syndromes arise in the context of PD-1 therapies, withdrawal of immune-activating medications [34] (Table 2). Therapeutic algorithms support the use of glucocorticoids, calcineurin inhibitors, mycophenolate mofetil, azathioprine, anti-CD20 antibodies and most recently, belimumab, which targets the cytokine B-cell activating factor (BAFF) [86]. Anti-CD20 antibodies bind CD20 on B cells and plasma cells and initiate cell death through several mechanisms, including apoptosis, antibody-dependent cell-mediated cytotoxicity and complement-dependent cell lysis [87]. Indirectly, antiCD20 antibodies may also protect the functions of podocytes through binding interactions with the cell surface receptor, sphingomyelin phosphodiesterase, acidlike 3b [88]. Anifrolumab, targeting the type I interferon receptor, has shown promise and may be soon approved for systemic lupus. Type I interferon cell signals also induce the expression of PD-L1 [89]. Additional research into the PD-1 response to pathogens and to autoimmunity may offer insight into the pathogenesis of glomerulonephritis and the adverse events that occur with PD-1 therapies.

\section{Glomerulonephritis summary}

The expression of PD-1 ligands on cells in the glomeruli or tubular epithelium during glomerulopathies has not been sufficiently explored. Macrophages and neutrophils are recruited during glomerulonephritis but only macrophages are identified to express PD-L1 in tissue. The expression and function of PD-1 on lymphocytes requires further investigation, particularly with respect to the double-negative $\mathrm{T}$ cells prominent in the kidney. Blocking CXCL10, IL-23 or IL-18 cell signals may induce lymphocyte PD-1 expression. Additional study of the PD-1 axis in glomerulonephritis may offer insight into the formation of germinal centers, fibrosis, and changes in erythropoietin production in the disease. Each of these concepts is important to understanding

Table 2 Identification PD-1, PD-L1 and PD-L2 expressing cells in the kidney

\begin{tabular}{|c|c|c|c|}
\hline Cell & Marker & Human & Mouse \\
\hline $\begin{array}{l}\text { Dendritic cells in the interstitium } \\
\text { and renal draining lymph [15] }\end{array}$ & $\begin{array}{l}\text { PD-L1, } \\
\text { PD-L2 }\end{array}$ & & $\begin{array}{l}\text { Fluorescently labeled dextrans or OT-I cells } \\
\text { injected into intravenously injected into C57BL/6, } \\
\text { OT-I.RAG }{ }^{-/-} \text {, Thy1.1, and/or Rag }{ }^{-/-} \text {mice }\end{array}$ \\
\hline $\begin{array}{l}\text { Human primary renal proximal } \\
\text { tubular epithelial cells (TECs) [6] }\end{array}$ & $\begin{array}{l}\text { PD-L1, } \\
\text { PD-L2 }\end{array}$ & $\begin{array}{l}\text { Primary cultures of human TECs generated } \\
\text { from healthy parts of tumor nephrectomies. }\end{array}$ & \\
\hline Immunotherapy patient TECs [9] & PD-L1 & $\begin{array}{l}\text { Kidney biopsies from anti-PD-1 immunotherapy } \\
\text { patients that developed acute interstitial nephritis } \\
\text { exhibit elevated TEC PD-L1 staining compared to } \\
\text { those with acute tubular necrosis }\end{array}$ & \\
\hline $\begin{array}{l}\text { Glomerulonephritis } \\
\text { macrophages [55] }\end{array}$ & PD-L1 & & $\begin{array}{l}\text { The lupus-prone NZM mouse strain +/- anti- } \\
\text { glomerular basement membrane (GBM) } \\
\text { antibodies }\end{array}$ \\
\hline Clear cell RCC macrophages [81] & $\begin{array}{l}\text { PD-L1, } \\
\text { PD-L2 }\end{array}$ & $\begin{array}{l}\text { A mass cytometry-based atlas of } 73 \text { RCC tumor } \\
\text { samples compared to five normal kidney controls }\end{array}$ & \\
\hline $\begin{array}{l}\text { Unknown cell source in clear } \\
\text { cell RCC patients [82] }\end{array}$ & $\begin{array}{l}\text { Soluble } \\
\text { PD-L1 }\end{array}$ & $\begin{array}{l}\text { Sera soluble PD-L1 levels from } 172 \text { RCC patients } \\
\text { correlates with pathologic features and patient } \\
\text { outcome }\end{array}$ & \\
\hline $\begin{array}{l}\text { Clear cell RCC and non-clear } \\
\text { cell RCC tumors [83] }\end{array}$ & $\begin{array}{l}\text { PD-L1, } \\
\text { PD-L2 }\end{array}$ & $\begin{array}{l}\text { In } 425 \text { resected RCCS, PD-L1 and PD-L2 expression } \\
\text { is variable among histologic subtypes and associated } \\
\text { with adverse outcomes in cCRCC }\end{array}$ & \\
\hline $\begin{array}{l}\mathrm{CD}^{+} \mathrm{CD} 25^{\text {hi }} \mathrm{FOXP3} 3^{+} \\
\text {(Tregs) in RCC patients [84] }\end{array}$ & PD-1 & $\begin{array}{l}\text { Primary tumor Tregs in } 42 \text { RCC patients displayed } \\
\text { elevated PD-1 compared to cells in the peripheral } \\
\text { blood of RCC patients and } 15 \text { healthy donors }\end{array}$ & \\
\hline $\mathrm{CD8}^{+} \mathbf{T}$ cells in $\mathrm{RCC}[85]$ & PD-1 & $\begin{array}{l}\text { In situ immunofluorescence spectral imaging of } \\
\text { RCC tissue from nephrectomy } \\
\text { revealed co-expression of PD- } 1 \text { and TIM-3 on CD8 }{ }^{+} \\
\text {associates with a more aggressive phenotype }\end{array}$ & \\
\hline
\end{tabular}


glomerulopathies that occur as an adverse event following to PD-1 immunotherapy.

\section{The PD-1 axis in RCC}

Renal cell carcinomas are heterogeneous in histology, cell of origin, and driver mutations [90]. RCC develops from renal tubular epithelial cells in the proximal, distal and collecting tubules [91]. Similar to glomerulonephritis, RCC tumors typically exhibit a mix of myeloid and lymphoid cell infiltrates [81], fibrosis [92], and in aggressive forms, lymphangiogenesis [93]. Unlike glomerulonephritis, erythropoietin production may be elevated in RCC [94] and B cells are not commonly detected in RCC [95]. These latter inverse manifestations between the diseases may be associated with the differential expression of hypoxic cell signals that induce the production of erythropoietin [94] and promote B cell apoptosis [96].

\section{RCC myeloid recruitment}

In clear cell RCC, mutations in the von Hippel-Lindau (VHL) E3 ubiquitin protein ligase prevent VHL-induced ubiquitination of hypoxia-inducible factor (HIF)- $1 \alpha$ and HIF- $2 \alpha$, which targets HIFs to the proteasome for degradation. This decreased degradation of HIF- $1 \alpha$ and HIF- $2 \alpha$ promotes hypoxic cell signals, which in turn promotes the production chemokines [97, 98]. RCC production of adrenomedullin [99], IL-8 [97], and CCL2 [100] contribute to the recruitment of mast cells, neutrophils and macrophages. The expression of membranebound macrophage colony-stimulating factor (mM-CSF) on RCC cells also contributes to the differentiation of monocytes to macrophages [101], which variably express PD-L1 and PD-L2 in tumor tissue [81]. The presence of these innate immune cells in RCC tumors enhances the production of vascular endothelial growth factor (VEGF), which is an angiogenic factor that has the potential to promote tumor growth and invasiveness [99, 101] (Fig. 3).

\section{RCC myeloid function}

In peripheral blood from RCC patients, an elevated neutrophil-to-lymphocyte ratio is associated with a poor prognosis. In a retrospective analysis of RCC patients treated with anti-PD-1 or anti-PD-L1-based regimens, a higher neutrophil-to-lymphocyte ratio measured sixweeks after therapy was independently associated with worse outcomes [102]. Because soluble PD-L1 is also a biomarker indicating poor prognosis in RCC [82], investigation of a mechanistic relationship between neutrophil function and soluble PD-L1 production may be warranted. Circulating neutrophil PD-L1 expression has not been evaluated in RCC. However, PD-1 is expressed on subsets of RCC-patient peripheral blood neutrophils, lymphocytes, and CD14 $4^{\text {bright }}$ myeloid cells and the levels of PD-1 on these cells correlates positively with RCC disease stage [103]. This may indicate that PD- $\mathrm{L}^{+} \mathrm{RCC}$ tumors [104] or PD-L1 ${ }^{+} \mathrm{PD}-\mathrm{L}^{+}{ }^{+} \mathrm{RCC}$ tumors [83] promote immunosuppression, in part by directly activating PD-1 on innate myeloid and lymphoid immune cells. Further studies are needed to test this hypothesis.

\section{$R C C T$ cell recruitment}

Expression of the chemokine stromal cell derived factor1 (SDF-1, also known as CXCL12) and its receptor, CXCR4, are induced by VHL inactivation and HIF stabilization. SDF-1 and CXCR4 are expressed in RCC tumors and are markers of poor prognosis [105]. Tregs isolated from primary RCC tumors express PD-1, CTLA-4 and high levels of CXCR4 [84]. NK cells can also express CXCR4 and PD-1 but are mostly characterized by the expression of immunosuppressive molecules CD158a, CD158b, and NKG2A/CD94 in RCC [106, 107]. The mechanisms involved in the recruitment of immunosuppressive NK cells and CD8 T cells in RCC are not well-understood.

\section{$R C C T$ cell function}

$\mathrm{CXCR}^{+} \mathrm{T}$ cell lines treated with SDF-1 induce the production of VEGF [108]. This growth factor, which is also abundantly produced by RCC tumor cells, activates the expression of three $\mathrm{CD}^{+} \mathrm{T}$ cell checkpoint receptor genes, encoding lymphocyte activation gene-3 (LAG3), T-cell immunoglobulin mucin-domain containing-3 (TIM-3) and PD-1 [109]. In RCC tumor tissue, $\mathrm{CD} 8^{+} \mathrm{T}$ cells express these receptors $[85,110]$ (Fig. 3). Because $\mathrm{CXCR}_{4}{ }^{+}$Tregs treated with a CXCR4 peptide antagonist effectively blocked Treg function and promoted interferon- $\gamma$ production [84], CXCR4 is a potential therapeutic target in RCC. Interestingly, CXCR4 is also a target in lupus glomerulonephritis [111] and the levels of interferon- $\gamma$ in this disease are elevated without the use of a CXCR4 antagonist [80]. Therefore, targeting VEGF receptors, PD-1, and/or additional checkpoints on $\mathrm{T}$ cells may be necessary to promote the development of tumor-specific $\mathrm{T}$ cells or effective $\mathrm{T}$ regulatory cells in glomerulonephritis.

\section{RCC treatment}

RCC-induced inflammatory cytokines and VHL mutations induce cell signals that activate the mammalian target of rapamycin (mTOR) pathway. These signals also contribute to RCC tumor cell activation of HIF- $1 \alpha$ and HIF- $2 \alpha$, which drive VEGF production and PD-L1 surface expression [112-114]. Treatments for RCC have primarily targeted VEGF ligands (bevacizumab), VEGF receptors (sorafenib, sunitinib, pazopanib, axitinib, cabozantinib), the mTOR pathway (temsirolimus, everolimus) 


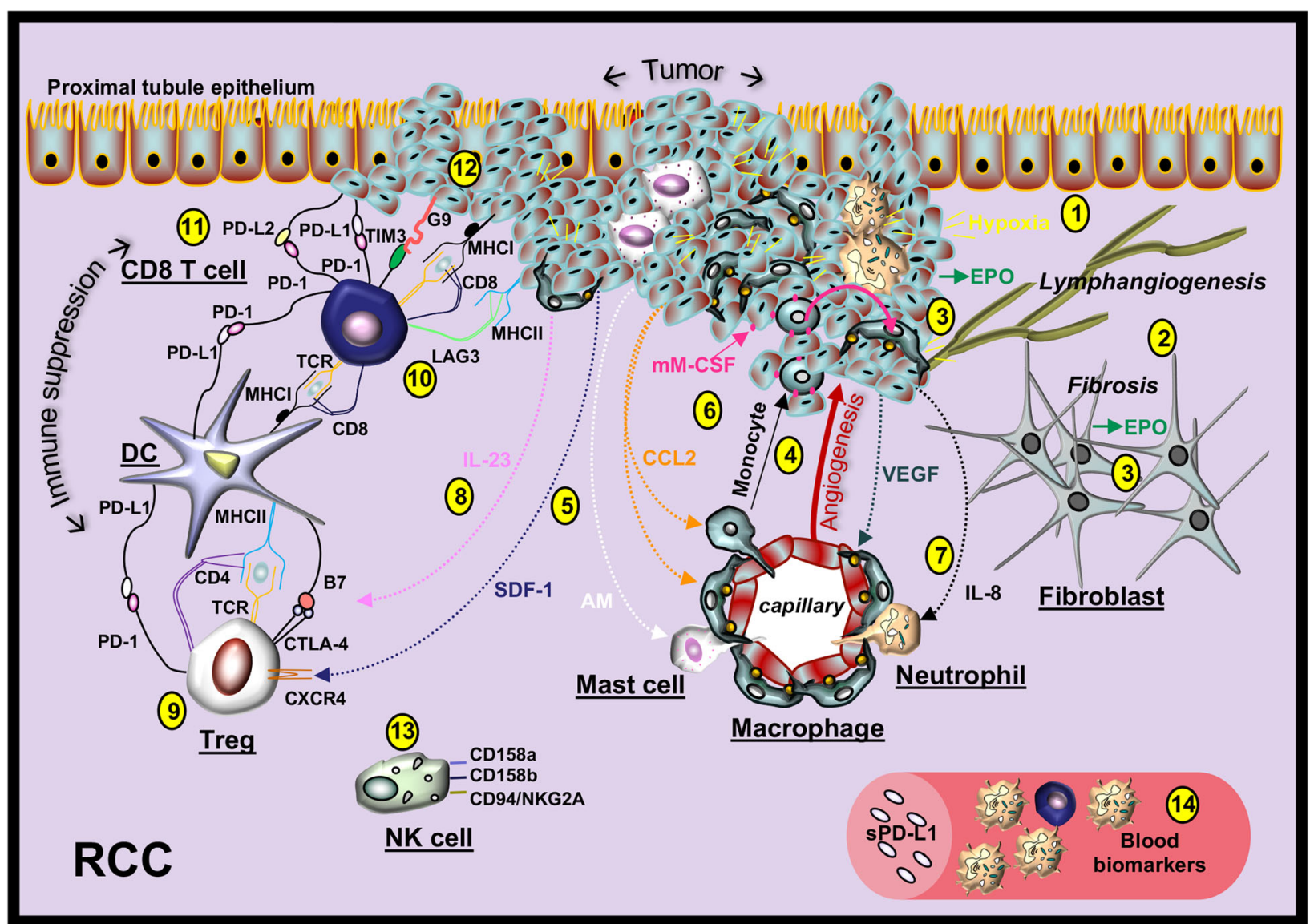

Fig. 3 The microenvironment in renal cell carcinoma (RCC). (1) A hypoxic microenvironment is induced by tumor cells and recruited mast cells, macrophages and neutrophils. (2) Intratumoral fibrotic lesions and lymphangiogenesis can occur in RCC. (3) Erythropoietin (EPO) is produced by tumor cells in addition to interstitial fibroblasts. (4) Tumor cells and immune cells produce vascular endothelial growth factor (VEGF), which promotes angiogenesis. (5) Tumor cells and epithelial cells produce stromal cell-derived factor 1 (SDF1) and adrenomedullin (AM) involved in the recruitment of lymphocytes and mast cells, respectively. (6) Tumor cells produce CCL2, which recruits macrophages and monocytes and membrane-type M-CSF (mM-CSF), which promotes monocyte to macrophage differentiation. (7) Tumor cells produce IL-8, which recruits neutrophils. (8) Macrophages produce IL-23 involved in Treg function. (9) RCC Tregs express PD-1 and CTLA-4. (10) RCC CD8 ${ }^{+}$T cells express lymphocyte activating-3 (LAG3), which binds RCC MHC class II in promoting tolerance. (11) Tumor cells can express PD-L1 and PD-L2 and either can bind T cell PD-1 receptors. (12) Tumor cells can also express galectin-9 (G9) that binds to the suppressive CD8 T cell marker T-cell immunoglobulin and mucin-domain containing-3 (TIM3). (13) Immunosuppressive NK cells are recruited in RCC. (14) RCC peripheral blood markers can include an elevated neutrophil to lymphocyte ratio and elevated plasma levels of SPD-L1

and more recently PD-1 (pembrolizumab, nivolumab) and PD-L1 (atezolizumab, avelumab, durvalumab) [115]. The similar and yet distinct activation networks in these pathways are important in understanding and predicting therapeutic responses in monotherapies and combinatorial treatments and in selecting the right therapy for a particular patient, who may have co-morbidities that impinge on or intersect with these pathways (Fig. 4).

\section{RCC summary}

RCC tumor cells may express PD-L1 and/or PD-L2. Macrophages variably express PD-L1 and PD-L2 in tumor tissue. Circulating myeloid and lymphoid cells may express PD-1, which can be regulated by SDF-1 or VEGF cell signals. These pathways are activated by hypoxic cell signals that often include the dysregulation of mTOR. In the kidney, vitamin D3, 5' AMP-activated protein kinase (AMPK) and glutathione are important to the physiological functions of the kidney and the cellular responses to hypoxia. The activation of PD-1 ligands by hypoxic cell signals also indicates that vitamin D3, AMPK and glutathione have a functional role in RCC and therapies that target mTOR, the PD-1 axis and VEGF.

\section{Vitamin D3 and the PD-1 axis}

Vitamin D3, derived from ultraviolet-B radiation of 7dehydrocholesterol in the skin or via dietary absorption, is 25-hydroxylated in the liver, predominantly by the P450 enzyme CYP2R1, to form $25(\mathrm{OH}) \mathrm{D}_{3}$. This 


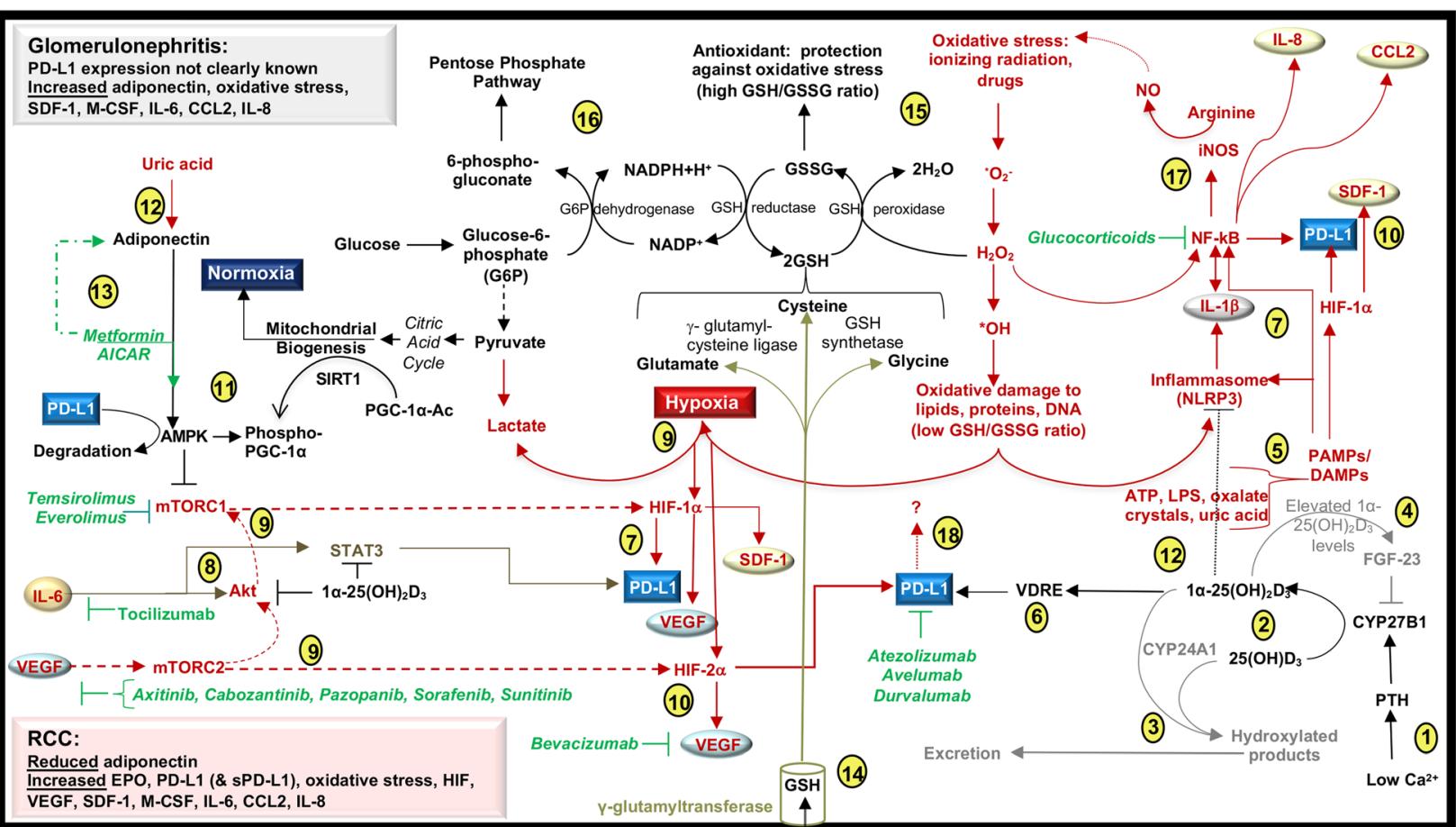

Fig. 4 Possible proximal tubule epithelial cell signals in glomerulonephritis and renal cell carcinoma. (1) Low levels of calcium induce the release of parathyroid hormone (PTH) from parathyroid glands and this stimulates renal CYP27B1 expression. (2) $25(\mathrm{OH}) \mathrm{D}_{3}$, formed in the liver, is hydroxylated by CYP27B1 to form the active metabolite, $1 \mathrm{a}-25(\mathrm{OH})_{2} \mathrm{D}_{3}$. (3) CYP24A1 catalyzes the conversion of $25(\mathrm{OH}) \mathrm{D}_{3}$ and $1 \mathrm{a}-25(\mathrm{OH})_{2} \mathrm{D}_{3}$ into 24-hydroxylated products targeted for excretion. (4) Elevated levels of $1 \mathrm{a}-25(\mathrm{OH})_{2} \mathrm{D}_{3}$ induce the production of fibroblast growth factor-23 (FGF23), which suppresses CYP27B1 transcription. (5) $1 \mathrm{a}-25(\mathrm{OH})_{2} \mathrm{D}_{3}$ may antagonize PAMP/DAMP-induced inflammasome activation. (6) Vitamin D response elements (VDRE) in the PD-L1 gene may be functionally active in the renal epithelium. (7) PAMPs/DAMPs, ROS, and IL-1 $\beta$ activate PD-L1 transcription factors, HIF-1a and NF-kB. PD-L1 expression can be blocked with monoclonal antibodies. (8) $1 \mathrm{a}-25(\mathrm{OH})_{2} \mathrm{D}_{3}$ antagonizes Akt and the transcription factor STAT3 that may be induced by IL-6 and mTORC2. IL-6 receptor monoclonal antibodies block IL-6 signals. (9) Hypoxia promotes the stability and activation of HIF-1a and HIF-2a. Both mTORC1 and mTORC2 are involved in HIF-1a regulation. mTORC2 regulates the expression of HIF-2a and is activated by VEGF cell signals. Tyrosine kinase inhibitors block VEGF receptor signals. (10) HIF-1a and HIF-2a induce the production of SDF-1 and VEGF. Antibodies that bind circulating VEGF block VEGF binding to its receptor. (11) Metformin-induced AMPK promotes PD-L1 phosphorylation and degradation. AMPK is also involved the phosphorylation of PGC-1a, which is additionally de-acetylated by sirtuins (SIRT1) during mitochondrial biogenesis and under conditions of normoxia. (12) Uric acid is a DAMP involved in the activation of the inflammasome and proximal tubule epithelial cell production of adiponectin. (13) Metformin and AICAR activate AMPK. Metformin therapy may induce the production of adiponectin. (14) Y-glutamyltransferase activity degrades glutathione (GSH) into its individual amino acids. (15) Reduced GSH scavenges free radicals and generates an oxidized form of GSH (GSSG). (16) GSH metabolism is associated with the activation of the pentose phosphate pathway. (17) NF-kB is antagonized by glucocorticoids and promotes the production of chemokines and ROS. (18) The cell signals that occur in response to PD-L1 ligation or blockade are not well characterized

molecule is subsequently 1-hydroxylated in the kidney by the proximal tubule epithelial cell enzyme 25hydroxyvitamin $\mathrm{D}_{3}$ 1- $\alpha$-hydroxylase (CYP27B1), forming the fully active metabolite, $1 \alpha-25(\mathrm{OH})_{2} \mathrm{D}_{3}[116,117]$. CYP27B1 activity is inhibited by fibroblast growth factor-23 (FGF-23), which in turn is induced by elevated levels of phosphate and $1 \alpha-25(\mathrm{OH})_{2} \mathrm{D}_{3}$. CYP27B1 activity is stimulated by parathyroid hormone (PTH). The synthesis and secretion of PTH is promoted by low plasma calcium and elevated plasma phosphate and is suppressed by physiologic plasma levels of $1 \alpha-25(\mathrm{OH})_{2} \mathrm{D}_{3}$ and fibroblast growth factor-23 [118]. With regard to catabolism, the mitochondrial 25-hydroxyvitamin $\mathrm{D}_{3}-24$ hydroxylase enzyme CYP24A1 catalyzes the conversion of both $25(\mathrm{OH}) \mathrm{D}_{3}$ and $1 \alpha-25(\mathrm{OH})_{2} \mathrm{D}_{3}$ into 24 hydroxylated products targeted for excretion [119]. Through these cell signals, the tubular cell regulates the levels of the most potent form of vitamin $D, 1 \alpha$ $25(\mathrm{OH})_{2} \mathrm{D}_{3}$, and thereby maintains bone mineral homeostasis. Whereas calcium filtered at the glomerulus is reabsorbed along the nephron, phosphate is primarily reabsorbed in the proximal tubule.

The CYP27B1 and CYP24A1 enzymes are also expressed by nearly all immune cell subsets [120]. In chronic kidney disease patients, levels of serum phosphate and FGF-23 are elevated, possibly in response to CYP27B1 loss of function, resulting in increased CYP24A1 activity and vitamin D3 deficiency [121] 
(Fig. 4). Altered expression of the vitamin D receptor (VDR) is also a prognostic indicator in chronic kidney disease [3]. The downstream signals of $1 \alpha-25(\mathrm{OH})_{2} \mathrm{D}_{3}$ also promote and inhibit PD-1 ligand expression.

\section{Vitamin D3 myeloid and epithelial cell signals}

In human myeloid and skin epithelial cell lines, $1 \alpha-$ $25(\mathrm{OH})_{2} \mathrm{D}_{3}$ enhances the expression of both PD-L1 and PD-L2 by binding to vitamin $\mathrm{D}$ response elements (VDRE) located near the gene [4]. Despite this similarity, additional cell signals in myeloid cells and epithelial cells manifest different responses to vitamin D. In myeloid cells, $1 \alpha-25(\mathrm{OH})_{2} \mathrm{D}_{3}$ interacts synergistically with pathogen- or damage-associated molecular patterns (PAMPs or DAMPs) in the activation of the NLRP3 inflammasome and subsequent production of IL-1 $\beta$ [122], which is a cytokine that induces PD-L1 expression [123]. $1 \alpha-$ $25(\mathrm{OH})_{2} \mathrm{D}_{3}$ activation of the $\mathrm{AKT} / \mathrm{mTOR}$ pathway also contributes to the formation of tolerogenic dendritic cells [124]. Regulation of the inflammasome by $1 \alpha-$ $25(\mathrm{OH})_{2} \mathrm{D}_{3}$ in kidney epithelial cells has not been deeply explored. However, in human corneal epithelial cells, $1 \alpha-25(\mathrm{OH})_{2} \mathrm{D}_{3}$ antagonizes NLRP3 inflammasome activation and reduces the production of reactive oxygen species (ROS) and IL-1 $\beta$ [125]. $1 \alpha-25(\mathrm{OH})_{2} \mathrm{D}_{3}$ also antagonizes the activity of STAT3, AKT and mTOR in a human renal proximal tubular epithelial cell line (HRPT EpiC) [126]. Therefore, $1 \alpha-25(\mathrm{OH})_{2} \mathrm{D}_{3}$ may inhibit epithelial cell activation of the mTOR complexes, mTOR complex 1 (mTORC1) and mTORC2 [127], and also inhibit their downstream signals, HIF- $1 \alpha$ and HIF- $2 \alpha$, which contribute to PD-L1 expression [114, 127]. Thus, the distinct cell signals that induce expression of PD-L1 on myeloid and epithelial cells may be regulated by $1 \alpha-$ $25(\mathrm{OH})_{2} \mathrm{D}_{3}$ through the disparate expression of the VDR and/or additional cell signals from PAMPs/DAMPs and cytokines that modulate signaling downstream of the VDR.

\section{Vitamin D3 $T$ cell signals}

VDR activation in T cells induces transcriptional repression of $I L-17 A$ but induction of FOXP3 [128], which also contain VDREs [129]. These responses may offer a mechanism to explain the inverse correlation between low serum $25(\mathrm{OH}) \mathrm{D}_{3}$ levels and the elevated IL-17 levels in SLE patients with $25(\mathrm{OH}) \mathrm{D}_{3}$ deficiency [130]. Treg and Th17 cells rely upon mTORC1 activity during differentiation $[131,132]$. This suggests that rapamycin analogs may antagonize the generation of both $\mathrm{T}$ cell subsets, which are differentially generated in response to $1 \alpha-25(\mathrm{OH})_{2} \mathrm{D}_{3}$ and differentially express PD-1 [43]. A possible mechanism to explain the $1 \alpha-25(\mathrm{OH})_{2} \mathrm{D}_{3}$ response in $\mathrm{T}$ cells may involve mTORC2 activity, which promotes the development of Tregs [133], possibly via
VEGF signaling [134]. A downstream signal of mTORC2 is mTORC1, which is a primary target in current clinical trials of RCC [115] and lupus [135]. Further research into $1 \alpha-25(\mathrm{OH})_{2} \mathrm{D}_{3}$ regulation in immune and nonimmune cells may yield insight into the functions of rapamycin analogs and other therapeutics that target products of mTOR activation (e.g., VEGF and PD-L1).

\section{Vitamin D3 summary}

Altered expression of the VDR is associated with chronic kidney disease and affects mTOR signals and the expression of PD- 1 and its ligands. VDR-induced mTORC1/2 signals differ in immune cells compared to epithelial cells, which may offer insight into the efficacies of mTOR inhibitors and PD-1 immunotherapies. The link between mTOR pathways and hypoxic metabolism also suggests that vitamin D3 is involved in the regulation of cellular hypoxia, which is a metabolic pathway highly activated in RCC and known to induce the expression of PD-1 ligands.

\section{AMPK and the PD-1 axis}

In immune cells and renal parenchymal cells, 5' AMPactivated protein kinase (AMPK) is activated in response to low intracellular ATP levels, resulting in AMPKmediated phosphorylation of multiple substrates involved in stimulating energy production and minimizing energy consumption [136]. AMPK promotes aerobic metabolism by activating a co-factor in mitochondrial biogenesis, specifically peroxisome proliferator -activated receptor gamma coactivator 1-alpha (PGC-1 $\alpha)$. AMPK also antagonizes mTORC1 and NF- $\mathrm{kB}$ cell signals, which collectively promote hypoxia [137].

\section{Adiponectin-induced AMPK}

Adiponectin is an endogenous activator of AMPK and induces anti-inflammatory responses in innate immune cell subsets [138]. This protein hormone is predominantly secreted by adipocytes but can also be generated by proximal tubule epithelial cells in response to a DAMP, soluble uric acid [139]. Adiponectin exhibits structural homology with the complement component, C1q, and both of these molecules activate AMPK in murine bone marrow-derived macrophages [140]. In lupus nephritis patients, both urine [141] and serum [142] levels of adiponectin are elevated compared to controls. In contrast, lower plasma adiponectin levels are associated with an increased incidence of RCC [143] (Fig. 4). Because serum levels of adiponectin tend to decrease with obesity [144], obesity may be a factor in the progression of RCC. Moreover, the adenosine analogue, 5 -amino-4-imidazole carboxamide riboside-1- $\beta$-D-ribofuranoside (AICAR), also activates AMPK and inhibits both mTORC1 activity and PD-L1 expression in lung 
cancer models [145], suggesting that adiponectininduced AMPK activation could have comparable functions in the kidney. Possibly, higher levels of adiponectin in glomerulonephritis reduce PD-L1 expression whereas lower adiponectin levels in RCC increase PD-L1 expression on proximal tubule epithelial cells.

\section{Metformin-induced AMPK}

Metformin, a plant-derived biguanide, is commonly used in the treatment of diabetes mellitus and induces AMPK activation through mechanisms that have not been fully elucidated [146]. In cultured breast cancer cells, metformin-induced AMPK activity promotes PD-L1 phosphorylation and subsequent endoplasmicreticulum-associated PD-L1 degradation [147]. In a murine melanoma model, a combination of metformin and PD-1 blockade results in improved intratumoral T-cell function and tumor clearance [148]. The effects of metformin on PD-L1-expressing proximal tubular epithelial cells and RCC tumor cells have not been fully explored. Metformin is being assessed in reducing disease activity flares in lupus patients (ClinicalTrials.gov Identifier: NCT02741960) and a combination of metformin and PD-1 blockade (nivolumab) is being tested in subjects with stage III-IV non-small cell lung cancers that cannot be surgically removed (ClinicalTrials.gov Identifier: NCT03048500). The outcomes of these trials may yield insight into the mechanisms of metformin in PD-1 immunity and kidney disease.

Moreover, retrospective studies of RCC patients receiving metformin for diabetes mellitus demonstrated improved overall survival in these patients compared to metformin non-users [149], particularly in localized non-metastatic RCC [150]. A retrospective study of type 2 diabetes patients showed that serum adiponectin levels increased with metformin therapy [151]. Higher levels of adiponectin with metformin therapy may therefore suggest a mechanism for improved outcomes in RCC [149] but possibly not in glomerulonephritis, where adiponectin levels are elevated in the absence of metformin [142]. However, because both metformin [152] and adiponectin [138] promote anti-inflammatory responses in immune cell subsets, additional study is warranted.

\section{AMPK summary}

AMPK activation in the kidney may inhibit mTORC1 cell signals and the expression of PD-L1. Adiponectin is an AMPK ligand that may be elevated in the plasma of lupus nephritis patients but reduced in RCC patients compared to controls. Obesity may therefore regulate PD-L1 expression in the kidney through adiponectin cells signals. The potential regulatory role of metformin in PD-L1 expression in the kidney requires further study.

\section{Glutathione and the PD-1 axis}

De novo production of the reduced form of glutathione (GSH) occurs via ligase and synthetase reactions that form a tripeptide composed of glutamic acid, cysteine, and glycine [153]. While most cells synthesize GSH, the liver is the primary source of circulating GSH, and the kidney is the primary tissue involved in the uptake of GSH from blood [154]. Renal proximal tubule epithelial cell $\gamma$-glutamyltransferase activity degrades GSH into its constituent amino acids. The recycling of these amino acids back into GSH and the conversion of oxidized glutathione (GSSG) to GSH via a GSH reductase are components of the GSH salvage synthesis pathway [153]. GSH reductive capacity is primarily driven by the pentose phosphate pathway, which generates GSH. Oxidation of GSH occurs through reactions with hydroxyl radicals $\left({ }^{\circ} \mathrm{OH}\right)$ or superoxide anion $\left(\mathrm{O}_{2}{ }^{-}\right)$. GSH can also be as a co-substrate of GSH peroxidases that reduce lipid peroxides and hydrogen peroxide $\left(\mathrm{H}_{2} \mathrm{O}_{2}\right)$ into alcohol or $\mathrm{H}_{2} \mathrm{O}$, respectively [153] (Fig. 4). Genetic variants in GSH enzymes (e.g., GPX1, GPX3) [155] or factors involved in the transcriptional regulation of GSH genes (e.g., NFE2l2, KEAP1) [156] may promote oxidative stress in both glomerulonephritis [157] and RCC [158]. These mutations may also affect plasma $25(\mathrm{OH}) \mathrm{D}_{3}$ levels since GSH plasma levels are positively correlated with plasma $25(\mathrm{OH}) \mathrm{D}_{3}$ levels in a study of obese adolescents, with further support from mouse studies [159]. A lack of GSH may also increase ROS, which in turn activates the transcription factors, NF-kB and HIF- $1 \alpha$, that regulate expression of CD274, encoding PD-L1 [160]. The role of ROS or GSH in the expression of PD-L1 in kidney immune or parenchymal cells remains to be fully explored.

\section{Glutathione summary}

By recycling GSH, kidney epithelial cells are constantly supplied with the factors required to synthesize this antioxidant. GSH can neutralize ROS involved in the activation of transcription factors that induce the expression of the PD-1 ligands. Changes in GSH plasma levels may be associated with PD-L1 expression and function.

\section{Comparing the immunobiology of RCC and glomerulonephritis}

The expression of PD-1 molecules in the kidney as discussed and displayed (Table 2) reveals the importance of these checkpoints and need for the additional study of PD- 1 and the PD-1 ligands in the kidney. The immunobiologic similarities and differences between glomerulonephritis and RCC may offer insight into the functions of these checkpoints. In both glomerulonephritis and RCC, epithelial cells and/or tumor cells produce CCL2 [53, 100], M-CSF [54, 101], and IL-8 [66, 97], which recruit monocytes and macrophages, promote monocyte- 
to-macrophage differentiation, and recruit neutrophils, respectively. RCC cells also produce the mast cell chemokine adrenomedullin [99], which could also be a factor in mast cell recruitment in glomerulonephritis [14, 161]. Notably, B cell recruitment and the formation of germinal centers in the kidney are seen, albeit rarely, in chronic glomerulonephritis [61] but not in RCC [95]. In the murine spleen, macrophages act as regulators of germinal center formation and this may indicate that the activation of macrophages is pivotal to germinal centers formation in the kidney [162]. Macrophages also produce IL-23 and IL-18, which contribute to the generation of Th17 and Th1 T cell subsets, respectively, in glomerulonephritis $[79,80]$. In an orthotopic model of kidney cancer, IL-23 blockade improved survival and enhanced the efficacy of PD-1 blockade, possibly by inhibiting IL-23-induced Tregs [163]. In a melanoma model, IL-18 therapy augments PD-L1 blockade by activating $\mathrm{CD}^{+} \mathrm{T}$ cells and NK cells but suppressing Tregs [164]. This tends to support in vitro data involving IL-2/IL-18 activated-NK cell cytotoxic killing of RCC cell lines [165]. The functional responses of IL-23 and IL-18 on double negative $\mathrm{TCR} \alpha \beta^{+} \mathrm{CD} 3^{+} \mathrm{CD} 4{ }^{-} \mathrm{CD} 8^{-} \mathrm{T}$ cells, which are highly expressed in the kidney [69] and can also express PD-1 [70], requires further study. Continued research into the functions of macrophages and the IL-18/ IL-23 balance may offer insight to the PD-1 axis in kidney disease.

The chemokine SDF-1 and its receptor CXCR4 are expressed both in glomerulonephritis and RCC [105, 111]. Data indicating that SDF-1 ligation to CXCR4 induces IL-6 production [166] may provide a rationale for the targeting of IL- 6 in both diseases $[167,168]$. An additional chemokine receptor, CXCR7/ACKR3, recognizes SDF-1, adrenomedullin and CXCL11 [169, 170]. This latter chemokine is also a CXCR3 ligand and a member of the interferon-inducible chemokine family, which also includes CXCL9, CXCL10 and CXCL11 [169]. Each of these CXCR3 family chemokines can be dysregulated in both glomerulonephritis [171] and RCC [172]. To add to the complexity, variants of the gene encoding CXCR3, CXCR3A and CXCR3B, are involved in promoting and inhibiting endothelial cell growth upon ligand binding, respectively [173]. Because CXCR3 ligation promotes the anti-tumor effects of PD-1 blockade in mice [174], further study of the CXCR3 variants, their ligands, and competing receptors on immune and parenchymal cells in the kidney may yield novel insights.

In RCC, hypoxia promotes the production of VEGF [113] and erythropoietin [94]. The paracrine signals between VEGF and HIF pathways may promote PD-L1 expression in RCC (Fig. 3) and lend support to clinical trials involving VEGF inhibitors and PD-1 targeted therapies [175]. Because VEGF is not only an important factor in angiogenesis, but also enhances the function of Tregs [134], T cell VEGF receptors may be a therapeutic target in glomerulonephritis and RCC. Targeting erythropoietin receptors on $\mathrm{T}$ cells may also be warranted, as erythropoietin is an additional factor that promotes the formation of immunosuppressive $\mathrm{T}$ cell subsets [64]. Consequently, erythropoietin and VEGF are candidate factors in regulating the expression and function of PD-1 in $\mathrm{T}$ cells but this remains to be demonstrated.

Finally, PD-L1 gene transcriptional activators include STAT1/3, NF-kB, HIF- $1 \alpha$, and HIF- $2 \alpha$ [176]. These transcription factors are induced by cytokine (e.g., IL-6, interferons, IL-1 $\beta$ ) and/or hypoxic cell signals (Fig. 3). These cell signals are differentially modulated by $1 \alpha-$ $25(\mathrm{OH})_{2} \mathrm{D}_{3}$ in immune cells $[122,124]$ and epithelial cells $[125,126]$. A mechanism underlying these diverse responses may involve GSH, particularly since renal proximal tubule epithelial cells are the primary cells responsible for GSH uptake from plasma [154]. GSH contributes to regulating the production of degradative enzymes (CYP24A1) and anabolic enzymes (CYP27B1), both of which determine $1 \alpha-25(\mathrm{OH})_{2} \mathrm{D}_{3}$ plasma and tissue levels [177]. In cultured proximal tubule epithelial cells, $1 \alpha-25(\mathrm{OH})_{2} \mathrm{D}_{3}$ also antagonizes mTOR [126], which is a direct target of rapamycin analogs and an indirect target of metformin and adiponectin (Fig. 3). Future research into the crosstalk among these pathways may identify markers for resistance to PD-1 therapy and additional therapeutic targets in glomerular disease.

\section{Conclusion}

Blocking PD-1 ligation with anti-PD-1 immunotherapy agents can induce various forms of glomerulonephritis. To understand the etiology of the effect, we have reviewed the possible expression and function of PD-1 receptors in a healthy kidney, glomerulonephritis and RCC. The PD-1 ligands, PD-L1 and PD-L2, are present on healthy proximal tubule epithelial cells in vivo and their expression is increased in some forms of RCC. Increased expression of PD-L1 also occurs in anti-PD-1 immunotherapy-induced acute interstitial nephritis, suggesting that the response may also occur in glomerulonephritis. In RCC, an elevated plasma level of soluble PD-L1 is a poor prognostic indicator. The cellular source and function of soluble PD-L1 in RCC has yet to be fully evaluated. In glomerulonephritis, serum levels of soluble PD-L1 could also be examined as a possible biomarker, particularly since 1, 25 dihydroxy-vitamin D3 is a factor in PD-L1 expression and levels of this vitamin are often low in chronic kidney disease in the absence of adequate supplementation. Mast cells, macrophages, neutrophils and $\mathrm{T}$ cells are similarly recruited to the kidney in both diseases, in which immunological processes 
manifest very differently. Because CXCR3 activation has a role in promoting the anti-tumor response in PD-1 immunotherapy, a better understanding of the ligands that bind CXCR3 variants (CXCR3A, CXCR3B) and competing receptors (CXCR4, CXCR7) is needed. Myeloid cells tend to express PD-L1 in glomerulonephritis but may express PD- 1 in RCC. The cell signals from these receptors on innate immune cells in the context of disease and immunotherapy requires further study. Erythropoietin, vitamin D3 and VEGF promote the formation of Tregs, suggesting that receptors for these molecules on $\mathrm{T}$ cells might be therapeutic targets in kidney disease and might also contribute to a possible PD-1 immunotherapeutic response. Because hypoxic cell signals induce the expression of PD-L1 molecules and promote B cell apoptosis, endogenous molecules that regulate hypoxic cell signals (e.g., AMPK, vitamin D3, GSH) and drugs that block hypoxic responses (e.g., rapamycin analogs, glucocorticoids, VEGF inhibitors) may increase the efficacy of PD-1 immunotherapies and the functions of B cells, including germinal center formation. Understanding these interconnected networks that regulate the PD1 response will be particularly important to identifying patients at increased risk for the development of glomerulonephritis as a complication of PD-1 immunotherapy.

\section{Abbreviations}

AICAR: 5-amino-4-imidazolecarboxamide riboside-1- $\beta$-D-ribofuranoside; AMPK: AMP-activated protein kinase; CCL2: Chemokine (C-C motif) ligand-2; CTLA-4: Cytotoxic T-lymphocyte-associated protein 4; DAMPS: Damageassociated molecular patterns; DC: Dendritic cell; FcR: Fc receptor; FDC: Follicular dendritic cell; FGF-23: Fibroblast growth factor-23; G9: Galectin-9; GSH: Reduced glutathione; GSSG: Oxidized glutathione; IL: Interleukin; HIF: Hypoxia-inducible factor; INF: Interferon; LAG3: Lymphocyte activation gene-3; MAC: Membrane attack complex; MHC: Major histocompatibility complex; M-CSF: Macrophage colonystimulating factor; mM-CSF: Membrane M-CSF; mTOR: Mammalian target of rapamycin; mTORC: mTOR complex; NK: Natural killer; PAMPs: Pathogenassociated molecular patterns; PD-1: Programmed death receptor-1; PDL1: PD-1 ligand; PD-L2: PD-1 ligand; PTH: Parathyroid hormone; RCC: Renal cell carcinoma; ROS: Reactive oxygen species; SDF-1: Stromal cell-derived factor-1; SIRT: Sirtuin; SPD-L1: Soluble PD-L1; TCR: T cell receptor; TIM-3: T-cell immunoglobulin mucin-domain containing-3; TNF: Tumor necrosis factor; VEGF: Vascular endothelial growth factor; VDR: Vitamin D receptor;

VDRE: Vitamin D response elements; VHL: von Hippel-Lindau

\section{Acknowledgements}

Not applicable

\section{Authors' contributions}

Wrote or contributed to the writing of the manuscript: CSC, JBK. Developed tables: CSC, JBK. Illustrations: CSC. The author(s) read and approved the final manuscript.

\section{Funding}

National Institutes of Health, Intramural Research Funds and NIDDK Intramural Research Program (ZO10-DK043308). Open Access funding provided by the National Institutes of Health $(\mathrm{NIH})$.

\section{Availability of data and materials}

All data generated or analyzed during this study are included in this published article
Ethics approval and consent to participate

Not applicable

\section{Consent for publication}

Not applicable.

\section{Competing interests}

The authors declare that the research was conducted in the absence of any commercial or financial relationships that could be construed as a potential conflict of interest.

\section{Author details}

${ }^{1}$ Critical Care Medicine Department, Clinical Center, NIH, BG 10 RM 2C135, 10 Center Drive, Bethesda, MD 20814, USA. ${ }^{2}$ Kidney Disease Section, NIDDK, NIH, Bethesda, MD, USA.

Received: 5 November 2020 Accepted: 31 January 2021

Published online: 06 March 2021

\section{References}

1. Scott RP, Quaggin SE. Review series: The cell biology of renal filtration. J Cell Biol. 2015;209(2):199-210.

2. Schodel J, Ratcliffe PJ. Mechanisms of hypoxia signalling: new implications for nephrology. Nat Rev Nephrol. 2019;15(10):641-59.

3. Yang S, Li A, Wang J, Liu J, Han Y, Zhang W, Li YC, Zhang H. Vitamin D Receptor: A Novel Therapeutic Target for Kidney Diseases. Curr Med Chem. 2018;25(27):3256-71

4. Dimitrov V, Bouttier M, Boukhaled G, Salehi-Tabar R, Avramescu RG, Memari B, Hasaj B, Lukacs GL, Krawczyk CM, White JH. Hormonal vitamin D upregulates tissue-specific PD-L1 and PD-L2 surface glycoprotein expression in humans but not mice. J Biol Chem. 2017;292(50):20657-68.

5. Noman MZ, Desantis G, Janji B, Hasmim M, Karray S, Dessen P, Bronte V, Chouaib S. PD-L1 is a novel direct target of HIF-1alpha, and its blockade under hypoxia enhanced MDSC-mediated T cell activation. J Exp Med. 2014; 211(5):781-90.

6. Starke A, Lindenmeyer MT, Segerer S, Neusser MA, Rusi B, Schmid DM, Cohen CD, Wuthrich RP, Fehr T, Waeckerle-Men Y. Renal tubular PD-L1 (CD274) suppresses alloreactive human T-cell responses. Kidney Int. 2010; 78(1):38-47.

7. Prokunina L, Gunnarsson I, Sturfelt G, Truedsson L, Seligman VA, Olson JL, Seldin MF, Criswell LA, Alarcon-Riquelme ME. The systemic lupus erythematosus-associated PDCD1 polymorphism PD1.3A in lupus nephritis. Arthritis Rheum. 2004;50(1):327-8.

8. Joseph RW, Millis SZ, Carballido EM, Bryant D, Gatalica Z, Reddy S, Bryce AH, Vogelzang NJ, Stanton ML, Castle EP, et al. PD-1 and PD-L1 Expression in Renal Cell Carcinoma with Sarcomatoid Differentiation. Cancer Immunol Res. 2015;3(12):1303-7.

9. Cassol C, Satoskar A, Lozanski G, Rovin B, Hebert L, Nadasdy T, Brodsky SV. Anti-PD-1 Immunotherapy May Induce Interstitial Nephritis With Increased Tubular Epithelial Expression of PD-L1. Kidney Int Rep. 2019;4(8):1152-60.

10. Mamlouk O, Selamet U, Machado S, Abdelrahim M, Glass WF, Tchakarov A, Gaber L, Lahoti A, Workeneh B, Chen S, et al. Nephrotoxicity of immune checkpoint inhibitors beyond tubulointerstitial nephritis: single-center experience. J Immunother Cancer. 2019;7(1):2.

11. Jung K, Zeng X, Bilusic M. Nivolumab-associated acute glomerulonephritis: a case report and literature review. BMC Nephrol. 2016;17(1):188.

12. Stamatiades EG, Tremblay ME, Bohm M, Crozet L, Bisht K, Kao D, Coelho C Fan X, Yewdell WT, Davidson A, et al. Immune Monitoring of Transendothelial Transport by Kidney-Resident Macrophages. Cell. 2016;166(4): 991-1003.

13. Kitching AR. Dendritic cells in progressive renal disease: some answers, many questions. Nephrol Dial Transplant. 2014;29(12):2185-93.

14. Holdsworth SR, Summers SA. Role of mast cells in progressive renal diseases. J Am Soc Nephrol. 2008;19(12):2254-61.

15. Lukacs-Kornek V, Burgdorf S, Diehl L, Specht S, Kornek M, Kurts C. The kidney-renal lymph node-system contributes to cross-tolerance against innocuous circulating antigen. J Immunol. 2008;180(2):706-15.

16. Gottschalk C, Damuzzo V, Gotot J, Kroczek RA, Yagita H, Murphy KM, Knolle PA, Ludwig-Portugall I, Kurts C. Batf3-dependent dendritic cells in the renal lymph node induce tolerance against circulating antigens. J Am Soc Nephrol. 2013;24(4):543-9. 
17. Nakae S, Suto H, likura M, Kakurai M, Sedgwick JD, Tsai M, Galli SJ. Mast cells enhance $T$ cell activation: importance of mast cell costimulatory molecules and secreted TNF. J Immunol. 2006;176(4):2238-48.

18. Curran CS, Sharon E. PD-1 immunobiology in autoimmune hepatitis and hepatocellular carcinoma. Semin Oncol. 2017;44(6):428-32.

19. Goldwich A, Burkard M, Olke M, Daniel C, Amann K, Hugo C, Kurts C, Steinkasserer A, Gessner A. Podocytes are nonhematopoietic professional antigen-presenting cells. J Am Soc Nephrol. 2013;24(6):906-16.

20. Chadban SJ, Tesch GH, Foti R, Lan HY, Atkins RC, Nikolic-Paterson DJ. Interleukin-10 differentially modulates MHC class II expression by mesangial cells and macrophages in vitro and in vivo. Immunology. 1998;94(1):72-8.

21. Vinen CS, Oliveira DB. Acute glomerulonephritis. Postgrad Med J. 2003; 79(930):206-13 quiz 212-203.

22. Khanna R. Clinical presentation \& management of glomerular diseases: hematuria, nephritic \& nephrotic syndrome. Mo Med. 2011;108(1):33-6.

23. Cruz-Whitley J, Giehl N, Jen KY, Young B. Membranoproliferative Glomerulonephritis Associated with Nivolumab Therapy. Case Rep Nephrol. 2020;2020:2638283

24. Daanen RA, Maas RJH, Koornstra RHT, Steenbergen EJ, van Herpen CML, Willemsen A. Nivolumab-associated Nephrotic Syndrome in a Patient With Renal Cell Carcinoma: A Case Report. J Immunother. 2017;40(9):345-8.

25. Gallan AJ, Alexander E, Reid P, Kutuby F, Chang A, Henriksen KJ. Renal Vasculitis and Pauci-immune Glomerulonephritis Associated With Immune Checkpoint Inhibitors. Am J Kidney Dis. 2019;74(6):853-6.

26. Uner M, Alhasson B, Obhrai J, Bagnasco SM. ANCA-associated pauciimmune necrotizing glomerulonephritis during the treatment with pembrolizumab. Virchows Arch. 2020.

27. Koda R, Watanabe H, Tsuchida M, lino N, Suzuki K, Hasegawa G, Imai N, Narita I. Immune checkpoint inhibitor (nivolumab)-associated kidney injury and the importance of recognizing concomitant medications known to cause acute tubulointerstitial nephritis: a case report. BMC Nephrol. 2018; 19(1):48

28. Bottlaender L, Breton AL, de Laforcade L, Dijoud F, Thomas L, Dalle S. Acute interstitial nephritis after sequential ipilumumab - nivolumab therapy of metastatic melanoma. J Immunother Cancer. 2017;5(1):57.

29. Glutsch V, Gran F, Weber J, Gesierich A, Goebeler M, Schilling B. Response to combined ipilimumab and nivolumab after development of a nephrotic syndrome related to PD-1 monotherapy. J Immunother Cancer. 2019;7(1): 181.

30. Escandon J, Peacock S, Trabolsi A, Thomas DB, Layka A, Lutzky J. Interstitial nephritis in melanoma patients secondary to PD-1 checkpoint inhibitor. J Immunother Cancer. 2017:5:3.

31. Tabei A, Watanabe M, Ikeuchi $H$, Nakasatomi M, Sakairi T, Kaneko $Y$, Maeshima A, Kaira K, Hirato J, Nojima Y, et al. The Analysis of Renal Infiltrating Cells in Acute Tubulointerstitial Nephritis Induced by Anti-PD-1 Antibodies: A Case Report and Review of the Literature. Intern Med. 2018; 57(21):3135-9.

32. Nakatani Y, Kawakami H, Ichikawa M, Yamamoto S, Otsuka Y, Mashiko A Takashima Y, Ito A, Nakagawa K, Arima S. Nivolumab-induced acute granulomatous tubulointerstitial nephritis in a patient with gastric cancer. Investig New Drugs. 2018;36(4):726-31.

33. Gao B, Lin N, Wang S, Wang Y. Minimal change disease associated with anti-PD1 immunotherapy: a case report. BMC Nephrol. 2018;19(1):156

34. Kodner CM, Kudrimoti A. Diagnosis and management of acute interstitial nephritis. Am Fam Physician. 2003;67(12):2527-34.

35. Perazella MA. Clinical Approach to Diagnosing Acute and Chronic Tubulointerstitial Disease. Adv Chronic Kidney Dis. 2017;24(2):57-63.

36. Nast CC. Medication-Induced Interstitial Nephritis in the 21st Century. Adv Chronic Kidney Dis. 2017;24(2):72-9.

37. Cortazar FB, Kibbelaar ZA, Glezerman IG, Abudayyeh A, Mamlouk O, Motwani SS, Murakami N, Herrmann SM, Manohar S, Shirali AC, et al. Clinica Features and Outcomes of Immune Checkpoint Inhibitor-Associated AKI: A Multicenter Study. J Am Soc Nephrol. 2020;31(2):435-46.

38. Martins F, Sofiya L, Sykiotis GP, Lamine F, Maillard M, Fraga M, Shabafrouz K, Ribi C, Cairoli A, Guex-Crosier Y, et al. Adverse effects of immune-checkpoint inhibitors: epidemiology, management and surveillance. Nat Rev Clin Oncol. 2019;16(9):563-80.

39. Vivarelli M, Massella L, Ruggiero B, Emma F. Minimal Change Disease. Clin J Am Soc Nephrol. 2017;12(2):332-45.

40. Rosenberg AZ, Kopp JB. Focal Segmental Glomerulosclerosis. Clin J Am Soc Nephrol. 2017;12(3):502-17.
41. Henderson $L$, Reoma LB, Kovacs JA, Nath A. Advances toward Curing HIV-1 Infection in Tissue Reservoirs. J Virol. 2020;94(3).

42. Sezgin E, An P, Winkler CA. Host Genetics of Cytomegalovirus Pathogenesis. Front Genet. 2019;10:616.

43. Curran CS, Gupta S, Sanz I, Sharon E. PD-1 immunobiology in systemic lupus erythematosus. J Autoimmun. 2019:97:1-9.

44. Johnson RJ, Floege J, Feehally J. CHAPTER 16 - Introduction to Glomerular Disease: Histologic Classification and Pathogenesis. In: Floege J, Johnson RJ, Feehally J, editors. Comprehensive Clinical Nephrology. 4th ed. Philadelphia: Mosby; 2010. p. 208-17.

45. Corvillo F, Okroj M, Nozal P, Melgosa M, Sanchez-Corral P, Lopez-Trascasa M. Nephritic Factors: An Overview of Classification, Diagnostic Tools and Clinical Associations. Front Immunol. 2019;10:886.

46. Pio R, Ajona D, Ortiz-Espinosa S, Mantovani A, Lambris JD. Complementing the Cancer-Immunity Cycle. Front Immunol. 2019;10:774

47. Iatropoulos P, Daina E, Curreri M, Piras R, Valoti E, Mele C, Bresin E, Gamba S, Alberti M, Breno M, et al. Cluster Analysis Identifies Distinct Pathogenetic Patterns in C3 Glomerulopathies/Immune Complex-Mediated Membranoproliferative GN. J Am Soc Nephrol. 2018;29(1):283-94.

48. Salvadori M, Rosso G. Reclassification of membranoproliferative glomerulonephritis: Identification of a new GN: C3GN. World J Nephrol. 2016:5(4):308-20.

49. Grywalska E, Smarz-Widelska I, Krasowska-Zajac E, Korona-Glowniak I, Zaluska-Patel K, Mielnik M, Podgajna M, Malm A, Rolinski J, Zaluska W. The PD-1/PD-L1 Inhibitory Pathway is Altered in Primary Glomerulonephritides. Arch Immunol Ther Exp (Warsz). 2018;66(2):133-43.

50. Anguiano L, Kain R, Anders HJ. The glomerular crescent: triggers, evolution, resolution, and implications for therapy. Curr Opin Nephrol Hypertens. 2020; 29(3):302-9.

51. Lionaki S, Boletis JN. The Prevalence and Management of Pauci-Immune Glomerulonephritis and Vasculitis in Western Countries. Kidney Dis (Basel). 2016:1(4):224-34.

52. Rovin BH, Yoshiumura T, Tan L. Cytokine-induced production of monocyte chemoattractant protein-1 by cultured human mesangial cells. J Immunol. 1992;148(7):2148-53.

53. Schmouder RL, Strieter RM, Kunkel SL. Interferon-gamma regulation of human renal cortical epithelial cell-derived monocyte chemotactic peptide1. Kidney Int. 1993:44(1):43-9.

54. Isbel NM, Nikolic-Paterson DJ, Hill PA, Dowling J, Atkins RC. Local macrophage proliferation correlates with increased renal M-CSF expression in human glomerulonephritis. Nephrol Dial Transplant. 2001;16(8):1638-47.

55. Sung SJ, Ge Y, Dai C, Wang H, Fu SM, Sharma R, Hahn YS, Yu J, Le TH, Okusa MD, et al. Dependence of Glomerulonephritis Induction on Nove Intraglomerular Alternatively Activated Bone Marrow-Derived Macrophages and Mac-1 and PD-L1 in Lupus-Prone NZM2328 Mice. J Immunol. 2017; 198(7):2589-601.

56. McIntosh LM, Barnes JL, Barnes VL, McDonald JR. Selective CCR2-targeted macrophage depletion ameliorates experimental mesangioproliferative glomerulonephritis. Clin Exp Immunol. 2009:155(2):295-303.

57. Law BMP, Wilkinson R, Wang X, Kildey K, Lindner M, Rist MJ, Beagley K, Healy $\mathrm{H}$, Kassianos AJ. Interferon-gamma production by tubulointerstitial human CD56(bright) natural killer cells contributes to renal fibrosis and chronic kidney disease progression. Kidney Int. 2017:92(1):79-88.

58. Cao Q, Harris DC, Wang Y. Macrophages in kidney injury, inflammation, and fibrosis. Physiology (Bethesda). 2015:30(3):183-94.

59. Olmos G, Munoz-Felix JM, Mora I, Muller AG, Ruiz-Torres MP, Lopez-Novoa JM, Rodriguez-Puyol D. Impaired erythropoietin synthesis in chronic kidney disease is caused by alterations in extracellular matrix composition. J Cell Mol Med. 2018;22(1):302-14.

60. Sakamoto I, Ito Y, Mizuno M, Suzuki Y, Sawai A, Tanaka A, Maruyama S, Take Y, Yuzawa Y, Matsuo S. Lymphatic vessels develop during tubulointerstitial fibrosis. Kidney Int. 2009;75(8):828-38.

61. Chang A, Henderson SG, Brandt D, Liu N, Guttikonda R, Hsieh C, Kaverina N, Utset TO, Meehan SM, Quigg RJ, et al. In situ B cell-mediated immune responses and tubulointerstitial inflammation in human lupus nephritis. J Immunol. 2011;186(3):1849-60.

62. Good-Jacobson KL, Szumilas CG, Chen L, Sharpe AH, Tomayko MM, Shlomchik MJ. PD-1 regulates germinal center $B$ cell survival and the formation and affinity of long-lived plasma cells. Nat Immunol. 2010;11(6):535-42.

63. Shi J, Hou S, Fang Q, Liu X, Liu X, Qi H. PD-1 Controls Follicular T Helper Cell Positioning and Function. Immunity. 2018;49(2):264-74 e264. 
64. Zhang Z, Liu D, Zhang X, Wang X. Erythropoietin Treatment Ameliorates Lupus Nephritis of MRL//pr Mice. Inflammation. 2018;41(5):1888-99.

65. Luo Q, Huang Z, Ye J, Deng Y, Fang L, Li X, Guo Y, Jiang H, Ju B, Huang $Q$, et al. PD-L1-expressing neutrophils as a novel indicator to assess disease activity and severity of systemic lupus erythematosus. Arthritis Res Ther. 2016;18:47.

66. Gerritsma JS, Hiemstra PS, Gerritsen AF, Prodjosudjadi W, Verweij CL, Van Es LA, Daha MR. Regulation and production of IL-8 by human proximal tubular epithelial cells in vitro. Clin Exp Immunol. 1996;103(2):289-94.

67. Niemir Zl, Stein H, Ciechanowicz A, Olejniczak P, Dworacki G, Ritz E, Waldherr R, Czekalski S. The in situ expression of interleukin-8 in the normal human kidney and in different morphological forms of glomerulonephritis. Am J Kidney Dis. 2004;43(6):983-98.

68. Van Kooten C, Boonstra JG, Paape ME, Fossiez F, Banchereau J, Lebecque S, Bruijn JA, De Fijter JW, Van Es LA, Daha MR. Interleukin-17 activates human renal epithelial cells in vitro and is expressed during renal allograft rejection J Am Soc Nephrol. 1998;9(8):1526-34.

69. Crispin JC, Oukka M, Bayliss G, Cohen RA, Van Beek CA, Stillman IE, Kyttaris VC, Juang YT, Tsokos GC. Expanded double negative T cells in patients with systemic lupus erythematosus produce IL-17 and infiltrate the kidneys. J Immunol. 2008:181(12):8761-6.

70. Rodriguez-Rodriguez N, Apostolidis SA, Fitzgerald L, Meehan BS, Corbett AJ, Martin-Villa JM, McCluskey J, Tsokos GC, Crispin JC. Pro-inflammatory selfreactive T cells are found within murine TCR-alphabeta(+) CD4(-) CD8(-) PD$1(+)$ cells. Eur J Immunol. 2016;46(6):1383-91.

71. Krohn S, Nies JF, Kapffer S, Schmidt T, Riedel JH, Kaffke A, Peters A, Borchers A, Steinmetz OM, Krebs CF, et al. IL-17C/ IL-17 Receptor E Signaling in CD4(+) T Cells Promotes TH17 Cell-Driven Glomerular Inflammation. J Am Soc Nephrol. 2018.

72. Masutani K, Akahoshi M, Tsuruya K, Tokumoto M, Ninomiya T, Kohsaka T, Fukuda K, Kanai H, Nakashima H, Otsuka T, et al. Predominance of Th1 immune response in diffuse proliferative lupus nephritis. Arthritis Rheum. 2001;44(9):2097-106

73. Steinmetz OM, Turner JE, Paust HJ, Lindner M, Peters A, Heiss $K$, Velden J, Hopfer H, Fehr S, Krieger T, et al. CXCR3 mediates renal Th1 and Th17 immune response in murine lupus nephritis. J Immunol. 2009; 183(7):4693-704.

74. Panzer U, Steinmetz OM, Paust HJ, Meyer-Schwesinger C, Peters A, Turner JE, Zahner G, Heymann F, Kurts C, Hopfer H, et al. Chemokine receptor CXCR3 mediates T cell recruitment and tissue injury in nephrotoxic nephritis in mice. J Am Soc Nephrol. 2007;18(7):2071-84.

75. Enghard P, Humrich JY, Rudolph B, Rosenberger S, Biesen R, Kuhn A, Manz R, Hiepe F, Radbruch A, Burmester GR, et al. CXCR3+CD4+ T cells are enriched in inflamed kidneys and urine and provide a new biomarker for acute nephritis flares in systemic lupus erythematosus patients. Arthritis Rheum. 2009;60(1):199-206

76. Narumi S, Takeuchi T, Kobayashi Y, Konishi K. Serum levels of ifn-inducible PROTEIN-10 relating to the activity of systemic lupus erythematosus. Cytokine. 2000;12(10):1561-5.

77. Peng W, Liu C, Xu C, Lou Y, Chen J, Yang Y, Yagita H, Overwijk WW, Lizee G, Radvanyi L, et al. PD-1 blockade enhances T-cell migration to tumors by elevating IFN-gamma inducible chemokines. Cancer Res. 2012;72(20):5209-18.

78. Shakweer MM, Behairy M, Elhefnawy NG, Elsaid TW. Value of Foxp3 expressing T-regulatory cells in renal tissue in lupus nephritis; an immunohistochemical study. J Nephropathol. 2016;5(3):105-10.

79. Zickert A, Amoudruz P, Sundstrom Y, Ronnelid J, Malmstrom V, Gunnarsson I. IL-17 and IL-23 in lupus nephritis - association to histopathology and response to treatment. BMC Immunol. 2015;16:7.

80. Calvani N, Richards HB, Tucci M, Pannarale G, Silvestris F. Up-regulation of IL-18 and predominance of a Th1 immune response is a hallmark of lupus nephritis. Clin Exp Immunol. 2004;138(1):171-8.

81. Chevrier S, Levine JH, Zanotelli VRT, Silina K, Schulz D, Bacac M, Ries CH, Ailles $L$, Jewett MAS, Moch $H$, et al. An Immune Atlas of Clear Cell Renal Cell Carcinoma. Cell. 2017;169(4):736-49 e718.

82. Frigola $\mathrm{X}$, Inman BA, Lohse CM, Krco CJ, Cheville JC, Thompson RH, Leibovich B, Blute ML, Dong H, Kwon ED. Identification of a soluble form of $\mathrm{B} 7-\mathrm{H} 1$ that retains immunosuppressive activity and is associated with aggressive renal cell carcinoma. Clin Cancer Res. 2011;17(7):1915-23.

83. Shin SJ, Jeon YK, Kim PJ, Cho YM, Koh J, Chung DH, Go H. Clinicopathologic Analysis of PD-L1 and PD-L2 Expression in Renal Cell Carcinoma: Association with Oncogenic Proteins Status. Ann Surg Oncol. 2016;23(2):694-702.
84. Santagata S, Napolitano M, D'Alterio C, Desicato S, Maro SD, Marinelli L, Fragale A, Buoncervello M, Persico F, Gabriele L, et al. Targeting CXCR4 reverts the suppressive activity of T-regulatory cells in renal cancer. Oncotarget. 2017:8(44):77110-20.

85. Granier C, Dariane C, Combe P, Verkarre V, Urien S, Badoual C, Roussel H, Mandavit M, Ravel P, Sibony M, et al. Tim-3 Expression on Tumor-Infiltrating PD-1(+)CD8(+) T Cells Correlates with Poor Clinical Outcome in Renal Cell Carcinoma. Cancer Res. 2017;77(5):1075-82.

86. Hahn BH, McMahon MA, Wilkinson A, Wallace WD, Daikh DI, Fitzgerald JD, Karpouzas GA, Merrill JT, Wallace DJ, Yazdany J, et al. American College of Rheumatology guidelines for screening, treatment, and management of lupus nephritis. Arthritis Care Res (Hoboken). 2012;64(6):797-808.

87. Boross P, Leusen JH. Mechanisms of action of CD20 antibodies. Am J Cancer Res. 2012;2(6):676-90.

88. Takahashi Y, Ikezumi Y, Saitoh A. Rituximab protects podocytes and exerts anti-proteinuric effects in rat adriamycin-induced nephropathy independent of B-lymphocytes. Nephrology (Carlton). 2017;22(1):49-57.

89. Bazhin AV, von Ahn K, Fritz J, Werner J, Karakhanova S. Interferon-alpha UpRegulates the Expression of PD-L1 Molecules on Immune Cells Through STAT3 and p38 Signaling. Front Immunol. 2018;9:2129.

90. Delahunt B, Srigley JR, Montironi R, Egevad L. Advances in renal neoplasia: recommendations from the 2012 International Society of Urological Pathology Consensus Conference. Urology. 2014;83(5):969-74.

91. Muglia VF, Prando A. Renal cell carcinoma: histological classification and correlation with imaging findings. Radiol Bras. 2015;48(3):166-74.

92. Joung JW, Oh HK, Lee SJ, Kim YA, Jung HJ. Significance of Intratumoral Fibrosis in Clear Cell Renal Cell Carcinoma. J Pathol Transl Med. 2018;52(5):323-30.

93. Debinski P, Dembowski J, Kowal P, Szydelko T, Kolodziej A, Malkiewicz B, Tupikowski K, Zdrojowy R. The clinical significance of lymphangiogenesis in renal cell carcinoma. Med Sci Monit. 2013;19:606-11.

94. Morais C, Johnson DW, Vesey DA, Gobe GC. Functional significance of erythropoietin in renal cell carcinoma. BMC Cancer. 2013;13:14.

95. Geissler K, Fornara P, Lautenschlager C, Holzhausen HJ, Seliger B, Riemann D. Immune signature of tumor infiltrating immune cells in renal cancer. Oncoimmunology. 2015;4(1):e985082.

96. Xu S, Huo J, Huang Y, Aw M, Chen S, Mak S, Yip LY, Ho YS, Ng SW, Tan AH, et al. von Hippel-Lindau Protein Maintains Metabolic Balance to Regulate the Survival of Naive B Lymphocytes. iScience. 2019:17:379-92.

97. Fitzgerald JP, Nayak B, Shanmugasundaram K, Friedrichs W, Sudarshan S, Eid AA, DeNapoli T, Parekh DJ, Gorin Y, Block K. Nox4 mediates renal cell carcinoma cell invasion through hypoxia-induced interleukin 6- and 8production. PLoS One. 2012;7(1):e30712.

98. Fujita Y, Mimata H, Nasu N, Nomura T, Nomura Y, Nakagawa M. Involvement of adrenomedullin induced by hypoxia in angiogenesis in human renal cell carcinoma. Int J Urol. 2002;9(6):285-95.

99. Chen Y, Li C, Xie H, Fan Y, Yang Z, Ma J, He D, Li L. Infiltrating mast cells promote renal cell carcinoma angiogenesis by modulating PI3K-->AKT->GSK3beta-->AM signaling. Oncogene. 2017;36(20):2879-88.

100. Arakaki R, Yamasaki T, Kanno T, Shibasaki N, Sakamoto H, Utsunomiya N, Sumiyoshi T, Shibuya S, Tsuruyama T, Nakamura E, et al. CCL2 as a potential therapeutic target for clear cell renal cell carcinoma. Cancer Med. 2016;5(10): 2920-33.

101. Komohara Y, Hasita H, Ohnishi K, Fujiwara Y, Suzu S, Eto M, Takeya M. Macrophage infiltration and its prognostic relevance in clear cell renal cell carcinoma. Cancer Sci. 2011;102(7):1424-31.

102. Lalani AA, Xie W, Martini DJ, Steinharter JA, Norton CK, Krajewski KM, Duquette A, Bosse D, Bellmunt J, Van Allen EM, et al. Change in Neutrophilto-lymphocyte ratio (NLR) in response to immune checkpoint blockade for metastatic renal cell carcinoma. J Immunother Cancer. 2018:6(1):5.

103. MacFarlane AW, Jillab M, Plimack ER, Hudes GR, Uzzo RG, Litwin S, Dulaimi E, Al-Saleem T, Campbell KS. PD-1 expression on peripheral blood cells increases with stage in renal cell carcinoma patients and is rapidly reduced after surgical tumor resection. Cancer Immunol Res. 2014;2(4):320-31.

104. Motoshima T, Komohara Y, Ma C, Dewi AK, Noguchi H, Yamada S, Nakayama T, Kitada S, Kawano Y, Takahashi W, et al. PD-L1 expression in papillary renal cell carcinoma. BMC Urol. 2017;17(1):8.

105. Wang L, Chen W, Gao L, Yang Q, Liu B, Wu Z, Wang Y, Sun Y. High expression of CXCR4, CXCR7 and SDF-1 predicts poor survival in renal cell carcinoma. World J Surg Oncol. 2012;10:212.

106. Xia Y, Zhang $Q$ Z Zhen $Q$ Z Zhao Y, Liu N, Li T, Hao Y, Zhang Y, Luo C, Wu X Negative regulation of tumor-infiltrating NK cell in clear cell renal cell 
carcinoma patients through the exosomal pathway. Oncotarget. 2017;8(23): 37783-95.

107. Schleypen JS, Von Geldern M, Weiss EH, Kotzias N, Rohrmann K, Schendel DJ, Falk CS, Pohla H. Renal cell carcinoma-infiltrating natural killer cells express differential repertoires of activating and inhibitory receptors and are inhibited by specific HLA class I allotypes. Int J Cancer. 2003;106(6):905-12.

108. Kijowski J, Baj-Krzyworzeka M, Majka M, Reca R, Marquez LA, ChristofidouSolomidou M, Janowska-Wieczorek A, Ratajczak MZ. The SDF-1-CXCR4 axis stimulates VEGF secretion and activates integrins but does not affect proliferation and survival in lymphohematopoietic cells. Stem Cells. 2001; 19(5):453-66.

109. Voron T, Colussi O, Marcheteau E, Pernot S, Nizard M, Pointet AL, Latreche S, Bergaya S, Benhamouda N, Tanchot C, et al. VEGF-A modulates expression of inhibitory checkpoints on CD8+ T cells in tumors. J Exp Med. 2015;212(2): 139-48.

110. Demeure CE, Wolfers J, Martin-Garcia N, Gaulard P, Triebel F. T Lymphocytes infiltrating various tumour types express the MHC class II ligand lymphocyte activation gene-3 (LAG-3): role of LAG-3/MHC class II interactions in cell-cell contacts. Eur J Cancer. 2001:37(13):1709-18.

111. Wang A, Guilpain P, Chong BF, Chouzenoux S, Guillevin L, Du Y, Zhou XJ, Lin F, Fairhurst AM, Boudreaux C, et al. Dysregulated expression of CXCR4/ CXCL12 in subsets of patients with systemic lupus erythematosus. Arthritis Rheum. 2010;62(11):3436-46.

112. Toschi A, Lee E, Gadir N, Ohh M, Foster DA. Differential dependence of hypoxia-inducible factors 1 alpha and 2 alpha on mTORC1 and mTORC2. Biol Chem. 2008:283(50):34495-9.

113. Shinojima T, Oya M, Takayanagi A, Mizuno R, Shimizu N, Murai M. Renal cancer cells lacking hypoxia inducible factor (HIF)-1alpha expression maintain vascular endothelial growth factor expression through HIF-2alpha. Carcinogenesis. 2007;28(3):529-36.

114. Ruf M, Moch H, Schraml P. PD-L1 expression is regulated by hypoxia inducible factor in clear cell renal cell carcinoma. Int J Cancer. 2016;139(2):396-403.

115. Rodriguez-Vida A, Hutson TE, Bellmunt J, Strijbos MH. New treatment options for metastatic renal cell carcinoma. ESMO Open. 2017;2(2):e000185.

116. Rosas-Peralta M, Holick MF, Borrayo-Sanchez G, Madrid-Miller A, Ramirez-Arias E, Arizmendi-Uribe E. Dysfunctional immunometabolic effects of vitamin D deficiency, increased cardiometabolic risk. Potential epidemiological alert in America? Endocrinol Diabetes Nutr. 2017;64(3):162-73.

117. Zhu JG, Ochalek JT, Kaufmann M, Jones G, Deluca HF. CYP2R1 is a major, but not exclusive, contributor to 25 -hydroxyvitamin $\mathrm{D}$ production in vivo. Proc Natl Acad Sci U S A. 2013;110(39):15650-5.

118. Lederer E. Regulation of serum phosphate. J Physiol. 2014;592(18):3985-95

119. Jones G, Prosser DE, Kaufmann M. 25-Hydroxyvitamin D-24-hydroxylase (CYP24A1): its important role in the degradation of vitamin D. Arch Biochem Biophys. 2012;523(1):9-18.

120. Medrano M, Carrillo-Cruz E, Montero I, Perez-Simon JA. Vitamin D: Effect on Haematopoiesis and Immune System and Clinical Applications. Int J Mol Sci. 2018;19(9).

121. Petkovich M, Jones G. CYP24A1 and kidney disease. Curr Opin Nephrol Hypertens. 2011;20(4):337-44.

122. Tulk SE, Liao KC, Muruve DA, Li Y, Beck PL, MacDonald JA. Vitamin D(3) metabolites enhance the NLRP3-dependent secretion of IL-1 beta from human THP-1 monocytic cells. J Cell Biochem. 2015;116(5):711-20.

123. Zong Z, Zou J, Mao R, Ma C, Li N, Wang J, Wang X, Zhou H, Zhang L, Shi Y. M1 Macrophages Induce PD-L1 Expression in Hepatocellular Carcinoma Cells Through IL-1 beta Signaling. Front Immunol. 2019;10:1643.

124. Ferreira GB, Vanherwegen AS, Eelen G, Gutierrez AC, Van Lommel L, Marchal K, Verlinden L, Verstuyf A, Nogueira T, Georgiadou M, et al. Vitamin D3 Induces Tolerance in Human Dendritic Cells by Activation of Intracellular Metabolic Pathways. Cell Rep. 2015.

125. Dai Y, Zhang J, Xiang J, Li Y, Wu D, Xu J. Calcitriol inhibits ROS-NLRP3-IL1 beta signaling axis via activation of Nrf2-antioxidant signaling in hyperosmotic stress stimulated human corneal epithelial cells. Redox Biol. 2019;21:101093.

126. Chung BH, Kim BM, Doh KC, Cho ML, Kim KW, Yang CW. Protective effect of 1alpha,25-dihydroxyvitamin D3 on effector CD4+ T cell induced injury in human renal proximal tubular epithelial cells. PLoS One. 2017;12(2): e0172536.

127. Fantus D, Rogers NM, Grahammer F, Huber TB, Thomson AW. Roles of mTOR complexes in the kidney: implications for renal disease and transplantation. Nat Rev Nephrol. 2016;12(10):587-609.
128. Joshi S, Pantalena LC, Liu XK, Gaffen SL, Liu H, Rohowsky-Kochan C, Ichiyama K, Yoshimura A, Steinman L, Christakos S, et al. 1,25dihydroxyvitamin $\mathrm{D}(3)$ ameliorates Th17 autoimmunity via transcriptional modulation of interleukin-17A. Mol Cell Biol. 2011;31(17):3653-69.

129. Kang SW, Kim SH, Lee N, Lee WW, Hwang KA, Shin MS, Lee SH, Kim WU, Kang I. 1,25-Dihyroxyvitamin D3 promotes FOXP3 expression via binding to vitamin $\mathrm{D}$ response elements in its conserved noncoding sequence region. J Immunol. 2012;188(11):5276-82

130. Shahin D, El-Farahaty RM, Houssen ME, Machaly SA, Sallam M, ElSaid TO, Neseem NO. Serum 25-OH vitamin D level in treatment-naive systemic lupus erythematosus patients: Relation to disease activity, IL-23 and IL-17. Lupus. 2017;26(9):917-26.

131. Kurebayashi $Y$, Nagai S, Ikejiri A, Ohtani M, Ichiyama K, Baba Y, Yamada T, Egami S, Hoshii T, Hirao A, et al. PI3K-Akt-mTORC1-S6K1/2 axis controls Th17 differentiation by regulating Gfil expression and nuclear translocation of RORgamma. Cell Rep. 2012;1(4):360-73.

132. Sun $I H$, Oh MH, Zhao L, Patel CH, Arwood ML, Xu W, Tam AJ, Blosser RL, Wen J, Powell JD. mTOR Complex 1 Signaling Regulates the Generation and Function of Central and Effector Foxp3(+) Regulatory T Cells. J Immunol. 2018;201(2):481-92.

133. Chang X, Lazorchak AS, Liu D, Su B. Sin1 regulates Treg-cell development but is not required for T-cell growth and proliferation. Eur J Immunol. 2012; 42(6):1639-47.

134. Zhu P, Hu C, Hui K, Jiang X. The role and significance of VEGFR2(+) regulatory T cells in tumor immunity. Onco Targets Ther. 2017;10:4315-9.

135. Lai ZW, Kelly R, Winans T, Marchena I, Shadakshari A, Yu J, Dawood M, Garcia R, Tily H, Francis $L$, et al. Sirolimus in patients with clinically active systemic lupus erythematosus resistant to, or intolerant of, conventional medications: a single-arm, open-label, phase 1/2 trial. Lancet. 2018; 391(10126): 1186-96

136. Hallows KR, Mount PF, Pastor-Soler NM, Power DA. Role of the energy sensor AMP-activated protein kinase in renal physiology and disease. Am J Physiol Ren Physiol. 2010;298(5):F1067-77.

137. Jeon SM. Regulation and function of AMPK in physiology and diseases. Exp Mol Med. 2016;48(7):e245.

138. Luo Y, Liu M. Adiponectin: a versatile player of innate immunity. J Mol Cell Biol. 2016;8(2):120-8.

139. Yang Q, Fu C, Xiao J, Ye Z. Uric acid upregulates the adiponectinadiponectin receptor 1 pathway in renal proximal tubule epithelial cells. Mol Med Rep. 2018;17(3):3545-54.

140. Galvan MD, Hulsebus H, Heitker T, Zeng E, Bohlson SS. Complement protein $\mathrm{Clq}$ and adiponectin stimulate Mer tyrosine kinase-dependent engulfment of apoptotic cells through a shared pathway. J Innate Immun. 2014;6(6): 780-92.

141. Brunner HI, Gulati G, Klein-Gitelman MS, Rouster-Stevens KA, Tucker L, Ardoin SP, Onel KB, Mainville R, Turnier J, Aydin POA, et al. Urine biomarkers of chronic kidney damage and renal functional decline in childhood-onset systemic lupus erythematosus. Pediatr Nephrol. 2019;34(1):117-28.

142. Diaz-Rizo V, Bonilla-Lara D, Gonzalez-Lopez L, Sanchez-Mosco D, FajardoRobledo NS, Perez-Guerrero EE, Rodriguez-Jimenez NA, Saldana-Cruz AM, Vazquez-Villegas ML, Gomez-Banuelos E, et al. Serum levels of adiponectin and leptin as biomarkers of proteinuria in lupus nephritis. PLoS One. 2017; 12(9):e0184056.

143. Wang H, Wu J, Gu W, Wang B, Wan F, Dai B, Zhang H, Shi G, Shen Y, Zhu Y, et al. Serum Adiponectin Level May be an Independent Predictor of Clear Cell Renal Cell Carcinoma. J Cancer. 2016;7(10):1340-6.

144. Achari AE, Jain SK. Adiponectin, a Therapeutic Target for Obesity, Diabetes, and Endothelial Dysfunction. Int J Mol Sci. 2017;18(6).

145. Lastwika KJ, Wilson W 3rd, Li QK, Norris J, Xu H, Ghazarian SR, Kitagawa H, Kawabata S, Taube JM, Yao S, et al. Control of PD-L1 Expression by Oncogenic Activation of the AKT-mTOR Pathway in Non-Small Cell Lung Cancer. Cancer Res. 2016;76(2):227-38.

146. Rena G, Hardie DG, Pearson ER. The mechanisms of action of metformin. Diabetologia. 2017;60(9):1577-85

147. Cha JH, Yang WH, Xia W, Wei Y, Chan LC, Lim SO, Li CW, Kim T, Chang SS, Lee $\mathrm{HH}$, et al. Metformin Promotes Antitumor Immunity via Endoplasmic-Reticulum-Associated Degradation of PD-L1. Mol Cell. 2018; 71(4):606-20 e607.

148. Scharping NE, Menk AV, Whetstone RD, Zeng X, Delgoffe GM. Efficacy of PD-1 Blockade Is Potentiated by Metformin-Induced Reduction of Tumor Hypoxia. Cancer Immunol Res. 2017;5(1):9-16. 
149. Li Y, Hu L, Xia Q, Yuan Y, Mi Y. The impact of metformin use on survival in kidney cancer patients with diabetes: a meta-analysis. Int Urol Nephrol. 2017:49(6):975-81.

150. Cheng JJ, Li H, Tan HS, Tan PH, Ng LG, Ng QS, Toh CK, Kanesvaran R, Tan $\mathrm{MH}$. Metformin Use in Relation With Survival Outcomes of Patients With Renal Cell Carcinoma. Clin Genitourin Cancer. 2016;14(2):168-75.

151. Su JR, Lu ZH, Su Y, Zhao N, Dong CL, Sun L, Zhao SF, Li Y. Relationship of Serum Adiponectin Levels and Metformin Therapy in Patients with Type 2 Diabetes. Horm Metab Res. 2016;48(2):92-8.

152. Ursini F, Russo E, Pellino G, D'Angelo S, Chiaravalloti A, De Sarro G, Manfredini R, De Giorgio R. Metformin and Autoimmunity: A "New Deal" of an Old Drug. Front Immunol. 2018;9:1236.

153. Lushchak VI. Glutathione homeostasis and functions: potential targets for medical interventions. J Amino Acids. 2012;2012:736837.

154. Lash LH. Role of glutathione transport processes in kidney function. Toxicol Appl Pharmacol. 2005;204(3):329-42.

155. Rudenko E, Kondratov O, Gerashchenko G, Lapska Y, Kravchenko S, Koliada O, Vozianov S, Zgonnyk Y, Kashuba V. Aberrant expression of seleniumcontaining glutathione peroxidases in clear cell renal cell carcinomas. Exp Oncol. 2015;37(2):105-10.

156. Nezu M, Suzuki N, Yamamoto M. Targeting the KEAP1-NRF2 System to Prevent Kidney Disease Progression. Am J Nephrol. 2017;45(6):473-83.

157. Shah SV, Baliga R, Rajapurkar M, Fonseca VA. Oxidants in chronic kidney disease. J Am Soc Nephrol. 2007;18(1):16-28.

158. Ganesamoni R, Bhattacharyya S, Kumar S, Chauhan A, Mete UK, Agarwal MM, Mavuduru R, Kaushik G, Mandal AK, Singh SK. Status of oxidative stress in patients with renal cell carcinoma. J Urol. 2012;187(4):1172-6.

159. Jain SK, Parsanathan $R$, Achari AE, Kanikarla-Marie $P$, Bocchini JA Jr. Glutathione Stimulates Vitamin D Regulatory and Glucose-Metabolism Genes, Lowers Oxidative Stress and Inflammation, and Increases 25Hydroxy-Vitamin D Levels in Blood: A Novel Approach to Treat 25Hydroxyvitamin D Deficiency. Antioxid Redox Signal. 2018;29(17):1792-807.

160. Gorlach A, Bonello S. The cross-talk between NF-kappaB and HIF-1: further evidence for a significant liaison. Biochem J. 2008;412(3):e17-9.

161. Mak A, Cheung BM, Mok CC, Leung R, Lau CS. Adrenomedullin--a potential disease activity marker and suppressor of nephritis activity in systemic lupus erythematosus. Rheumatology (Oxford). 2006;45(10):1266-72.

162. Nikbakht N, Shen S, Manser T. Cutting edge: Macrophages are required for localization of antigen-activated B cells to the follicular perimeter and the subsequent germinal center response. J Immunol. 2013;190(10):4923-7.

163. Fu Q, Xu L, Wang Y, Jiang Q, Liu Z, Zhang J, Zhou Q, Zeng H, Tong S, Wang T, et al. Tumor-associated Macrophage-derived Interleukin-23 Interlinks Kidney Cancer Glutamine Addiction with Immune Evasion. Eur Urol. 2019; 75(5):752-63.

164. Ma Z, Li W, Yoshiya S, Xu Y, Hata M, El-Darawish Y, Markova T, Yamanishi K, Yamanishi $\mathrm{H}$, Tahara $\mathrm{H}$, et al. Augmentation of Immune Checkpoint Cancer Immunotherapy with IL18. Clin Cancer Res. 2016;22(12):2969-80.

165. Senju H, Kumagai A, Nakamura Y, Yamaguchi H, Nakatomi K, Fukami S, Shiraishi K, Harada Y, Nakamura M, Okamura H, et al. Effect of IL-18 on the Expansion and Phenotype of Human Natural Killer Cells: Application to Cancer Immunotherapy. Int J Biol Sci. 2018;14(3):331-40.

166. Chen HT, Tsou HK, Hsu CJ, Tsai CH, Kao CH, Fong YC, Tang CH. Stromal cellderived factor-1/CXCR4 promotes IL-6 production in human synovial fibroblasts. J Cell Biochem. 2011;112(4):1219-27.

167. Su H, Lei CT, Zhang C. Interleukin-6 Signaling Pathway and Its Role in Kidney Disease: An Update. Front Immunol. 2017;8:405.

168. Ishibashi K, Haber T, Breuksch I, Gebhard S, Sugino T, Kubo H, Hata J, Koguchi T, Yabe M, Kataoka M, et al. Overriding TKI resistance of renal cell carcinoma by combination therapy with IL-6 receptor blockade. Oncotarget. 2017;8(33):55230-45.

169. Singh AK, Arya RK, Trivedi AK, Sanyal S, Baral R, Dormond O, Briscoe DM, Datta D. Chemokine receptor trio: CXCR3, CXCR4 and CXCR7 crosstalk via CXCL11 and CXCL12. Cytokine Growth Factor Rev. 2013;24(1):41-9.

170. Wang C, Chen W, Shen J. CXCR7 Targeting and Its Major Disease Relevance. Front Pharmacol. 2018;9:641.

171. Liao X, Pirapakaran T, Luo XM. Chemokines and Chemokine Receptors in the Development of Lupus Nephritis. Mediat Inflamm. 2016;2016:6012715.

172. Liu W, Liu Y, Fu Q, Zhou L, Chang Y, Xu L, Zhang W, Xu J. Elevated expression of IFN-inducible CXCR3 ligands predicts poor prognosis in patients with non-metastatic clear-cell renal cell carcinoma. Oncotarget. 2016;7(12):13976-83.
173. Lasagni L, Francalanci M, Annunziato F, Lazzeri E, Giannini S, Cosmi L, Sagrinati C, Mazzinghi B, Orlando C, Maggi E, et al. An alternatively spliced variant of CXCR3 mediates the inhibition of endothelial cell growth induced by IP-10, Mig, and I-TAC, and acts as functional receptor for platelet factor 4 . J Exp Med. 2003;197(11):1537-49.

174. Han X, Wang Y, Sun J, Tan T, Cai X, Lin P, Tan Y, Zheng B, Wang B, Wang J, et al. Role of CXCR3 signaling in response to anti-PD-1 therapy. EBioMedicine. 2019;48:169-77.

175. Yi M, Jiao D, Qin S, Chu Q, Wu K, Li A. Synergistic effect of immune checkpoint blockade and anti-angiogenesis in cancer treatment. Mol Cancer. 2019;18(1):60.

176. Zerdes I, Matikas A, Bergh J, Rassidakis GZ, Foukakis T. Genetic, transcriptional and post-translational regulation of the programmed death protein ligand 1 in cancer: biology and clinical correlations. Oncogene. 2018.

177. Parsanathan R, Jain SK. Glutathione deficiency alters the vitamin Dmetabolizing enzymes CYP27B1 and CYP24A1 in human renal proximal tubule epithelial cells and kidney of HFD-fed mice. Free Radic Biol Med. 2019;131:376-81.

\section{Publisher's Note}

Springer Nature remains neutral with regard to jurisdictional claims in published maps and institutional affiliations.

\section{Ready to submit your research? Choose BMC and benefit from:}

- fast, convenient online submission

- thorough peer review by experienced researchers in your field

- rapid publication on acceptance

- support for research data, including large and complex data types

- gold Open Access which fosters wider collaboration and increased citations

- maximum visibility for your research: over $100 \mathrm{M}$ website views per year

At BMC, research is always in progress.

Learn more biomedcentral.com/submissions 